\title{
Bank Performance in China: A Perspective from Bank Efficiency, Risk-taking and Market Competition
}

\author{
Jianchun Fang, Ph.D. \\ Zhejiang University, Hangzhou, China \\ Zhejiang University of Technology, Hangzhou, China \\ Email : fangjianchun@zju.edu.cn
}

Chi-Keung Marco Lau

University of Huddersfield, Huddersfield, the United Kingdom

E-mail: c.lau@hud.ac.uk

Zhou Lu

Tianjin University of Commerce, China

E-mail: luzhou59@gmail.com

Yong Tan

University of Huddersfield, Huddersfield, the United Kingdom

E-mail: a.y.tan@hud.ac.uk

\section{Hua Zhang}

(Corresponding Author)

School of Economics, Zhejiang University, China

E-mail: prozhwa@126.com 


\begin{abstract}
The current paper contributes to the empirical literature on bank profitability by testing the jointimpact of different types of risk, competition in different banking markets and different types of efficiency on bank profitability using a sample of Chinese commercial banks over the period 20032017. In particular, we fill in the gap of the empirical studies by examining the impact of efficiency on profitability when banks undertake different levels of risk-taking behaviour and face different degrees of competition. The results show that competition in the Chinese banking markets (deposit market, loan market and non-interest income market) is stronger over the period 2003-2005 and also 2014-2017. In addition, it is found that bank size, cost efficiency, profit efficiency and inflation are significantly related to bank profitability. Finally, we find that the positive impact of cost efficiency on profitability is stronger when banks undertake higher levels of risk and face more competition.
\end{abstract}

Keywords: interest rate liberalization, bank competition, bank efficiency, bank profitability, China

JEL classification: G21, C23 


\section{Introduction}

The Chinese banking sector has undergone a sustainable and healthy development through several rounds of banking reforms initiated by the government since 1978. The main purpose of these banking reforms has been to increase competitive conditions, enhance stability and improve performance of the Chinese banking sector. With regards to the competitive conditions, it is noticed that the state-owned commercial banks (SOCBs) still dominate the industry. However, according to statistics from the China Banking Regulatory Commission (CBRC), the share of SOCB assets in total banking sector assets decreased between 2003 and 2017 to a low point of $36.77 \%$. On the other hand, the city commercial banks (CCBs) has kept increasing in size and in 2017, they held $12.57 \%$ of total banking sector assets, while although the joint-stock commercial banks (JSCBs) experienced a slight volatile of the size of their assets, by the end of 2017, they held $17.81 \%$ of total banking sector assets, which was higher than the figures before 2011 Therefore, the statistic shows that the competitive condition is still quite low under the consideration that five largest banks hold more than $35 \%$ of total banking sector assets. Table 1 summarizes the assets of SOCBs, JSCBs, CCBs and total banking institutions in China over the period 2003-2017.

\section{$<<$ Table 1---about here >>}

The impact of competition on profitability in the banking industry has been documented in the traditional structure-conduct-performance (SCP) paradigm, which argues that in a higher concentrated industry with a lower level of competition, firms tend to collude with each other to obtain higher profits. In addition, there is a large number of literature investigating the impact of competition on profitability in the banking industry (Maudos and Fernandez de Guevara, 2004; 
Tan and Floros, 2014; Tan, 2016; among others). In comparison to the traditional SCP hypothesis discussed above, the efficient-structure hypothesis (ES) argues that it is the superior efficiency rather than the collusive behaviour that actually leads to an improvement in bank profitability. The accounting cost-income ratio or parametric stochastic frontier estimation is used to derive the bank efficiency by the empirical literature. The empirical literature has different findings with regard to the impact of efficiency on bank profitability (Berger, 1995, Garcia-Herrero et al., 2009; among others). More recently, there are articles investigating the competitive conditions in different banking markets in China (Tan, 2017, Wang and Wang, 2016, among others). Through consistent efforts made by the CBRC since 2003, the Chinese banking industry has in general reduced the level of its risk-taking behaviour from different perspectives. The impact of the risk-taking behaviour on bank profitability has been extensively tested by the empirical literature focusing on European countries, United States, Emerging Economies as well as the Chinese banking industry. More specifically, Tan (2016) tests the insolvency risk in the Chinese banking industry and further examines its impact on bank profitability. The results show that there is no impact of insolvency risk on bank profitability in China over the period 2003-2011.

Our paper contributes to the empirical banking literature by the following three ways: 1) we are the first piece of research evaluating the joint impacts of competition in different banking markets, different types of risk and different types of efficiencies on profitability using a sample of Chinese commercial banks over the period 2003-2017; 2) we produce the most robustness results by using a number of different alternative tests including different variables, different samples as well as different econometric techniques; 3 ) our paper contributes to the empirical literature by testing and compare the impact of efficiency on profitability when banks engage in different levels of risktaking behaviour and face different degrees of competition. 
One of the important banking reforms in China is interest rate liberalization. This reform makes the interest rate on loans and interest rate on deposit determined by the market force rather than the government. In order to improve the competitive conditions in deposit market and loan market, the Central Bank of China- the Peoples' Bank of China, has taken efforts to liberalize the interest rate since 1996 . From $20^{\text {th }}$ July 2013 and $23^{\text {rd }}$ October 2015, the loan interest rate, as well as the deposit interest rate in China, have been liberalized. The process of interest rate liberalization in these two different markets is supposed to have an impact on their competitive conditions. In the Chinese banking industry, the traditional interest generating activities still contribute to the largest proportion of bank income. However, the interest generating activities are affected significantly by economic cycles as well as credit risk. Thus, Chinese commercial banks have gradually developed a series of non-interest generating businesses, which not only can reduce bank risk but also significantly promote bank profitability.

Our results show that interest rate liberalization is effective in increasing the competitive condition in the Chinese banking industry, as evidenced by a stronger competition after 2013. We further report that profitability in the Chinese banking industry is significantly affected by bank size, cost efficiency, profit efficiency and inflation. Finally, the findings suggest that the positive impact of efficiency on profitability is stronger when banks have higher levels of risk and face a stronger competition.

The current paper is structured as follows: section 2 reviews the empirical literature investigating profitability in the Chinese banking industry, followed by section 3 presenting the methodology and data used in the paper. Section 4 discusses the empirical results, followed by section 5 
reporting and discussing the additional robustness check and additional tests. Finally, section 6 concludes the paper.

\section{Literature review on investigating profitability in the Chinese banking industry}

The profitability in the Chinese banking sector has been extensively tested by the empirical literature. Shih et al. (2007) evaluate the performance of a sample of Chinese commercial banks in 2002 under a principal analysis. The results indicate that JSCBs perform better compared to SOCBs and CCBs. Their findings further suggest that bank size does not have any significant impact on bank performance. Although they consider the bank-specific factors influencing bank profitability, the industry and macroeconomic factors are not excluded from the analysis.

Using a sample of Chinese commercial banks over the period 2000-2005, Sufian and Habibullah (2009) investigate the impact of credit risk on bank profitability. Their results suggest that credit risk has a significant and positive impact on the profitability of SOCBs and JSCBs. In addition, Sufian (2009) uses four SOCBs and JSCBs during 2000-2007 to examine the determinants of bank profitability in China with a focus on the impact of credit risk and liquidity risk under a fixed effect model. The results show that Chinese commercial banks with higher levels of credit risk and liquidity risk have higher profitability. Both of these two studies suffer from a number of limitations: first and foremost, they only investigate two types of risk, while capital risk and insolvency risk are missing in the studies; secondly, the fixed effect model is unable to provide an accurate and robust result compared to a Generalized Method of Moments (GMM) estimator. Thirdly, efficiency, which is a very important determinant of bank profitability, as documented by the efficient-structure (ES) hypothesis, is not considered in the studies. 
Heffernan and $\mathrm{Fu}(2010)$ analyse the profitability of Chinese commercial banks over the period 1999-2006 using two econometric techniques including a Generalized Method of Moments (GMM) estimator as well as a fixed effect estimator. Their findings report that bank efficiency, bank listing, GDP growth rate and unemployment are significantly related to bank profitability. Although this study provides a robust result with regard to the determinants of profitability in the Chinese banking industry, the risk factors are not controlled.

More recently, Tan and Floros (2012a, 2012b, 2012c) use a sample of Chinese commercial banks over the period 2003-2009 to examine the determinants of bank profitability with a focus on the impacts of credit risk and competition on bank profitability under a GMM estimator. The competition is measured by 3-bank and 5-bank concentration ratios. To be more specific, Tan and Floros (2012a) use both 3-bank concentration ratio and 5-bank concentration ratio to investigate the joint effects of credit risk and competition on bank profitability in China. They do not find any significant impact. The findings from Tan and Floros (2012b) show that the profitability of Chinese commercial banks is significantly affected by credit risk. Finally, the results from Tan and Floros (2012c) report that JSCBs with higher levels of credit risk have higher profitability.

Using a sample of Chinese commercial banks over the period 2003-2009, Tan and Floros (2014) investigate the inter-relationships between risk, profitability and competition, two types of risk are considered which are credit risk and insolvency risk, while the competitive condition is measured by Lerner index. They also use the Seemingly Unrelated Regression to analyze the interrelationships. The results show that there is a negative impact of competition on bank profitability, while there is no robust impact of different types of risk on bank profitability. Using a sample of Chinese commercial banks over the period 1997-2004, Garcia-Herrero et al. (2009) explain the 
low profitability in the Chinese banking industry with a focus on the impacts of competition and efficiency on bank profitability. The authors use a GMM estimator as the econometric technique. The efficiency is measured by the parametric stochastic frontier approach, while the competition is measured by the Herfindahl-Hirshman index. The results show that Chinese commercial banks with a higher level of efficiency have higher profitability and there is no clear impact of competition on bank profitability. More recently, Tan (2016) uses a sample of Chinese commercial banks over the period 2003-2011 to examine the impacts of risk and competition on bank profitability in China under a GMM estimation. Two types of risk are evaluated which are credit risk and insolvency risk, while the competition is measured by the Lerner index. The results show that there is no robust impacts of risk and competition on bank profitability in China.

Using a sample of Chinese commercial banks over the period 2003-2013, Tan et al. (2017) investigate the joint-impact of different types of risk, cost efficiency and competition on profitability. there are five different types of risk considered including credit risk, liquidity risk, capital risk, security risk and insolvency risk, the overall level of competitive condition is measured by the Lerner index and 3-bank concentration ratio, while the cost efficiency is measured under a stochastic frontier analysis. The results from the GMM estimator show that different types of risk and competition are significantly related to bank profitability in China, while the impact of cost efficiency on bank profitability is insignificant.

Tan (2017) uses a sample of 100 Chinese commercial banks over the period 2003-2013 to investigate the joint-impacts of competition and shadow banking on profitability. The competitive condition is measured by Boone (2008) indicator to reflect the levels of competition in three different banking markets (deposit market, loan market and non-interest income market). The 
results show that non-interest income market has a higher level of competition compared to deposit market and loan market,while a lower level of competition in the deposit market leads to an increase in bank profitability in China. Finally, the findings suggest that the volumes of shadow banking have a significant and positive impact on bank profitability. Similarly, Wang and Wang (2016) also test the competition in different banking markets in China (deposit market, loan market and non-interest income market), they have similar results as reported by Tan (2017).

\section{Methodology and data}

\subsection{Measurement of competition in different banking markets in China}

The current study uses the method proposed by Boone (2008) to measure the competition. The Bonne indicator holds the idea that the performance of efficient firms is improved and the performance of inefficient firms is weakened by competition. The basic logic of Boone indicator is in line with the argument of efficiency structure hypothesis as developed by Demsetz (1973) which links the influence of efficiency on performance. The performance can be measured by profit or market share. The stronger effect will lead to a more negative Boone indicator. The Boone indicator for bank i can be defined by the simplest equation as follows:

$$
L N\left(M S_{k i}\right)=\alpha+\beta L N\left(M C_{k i}\right)
$$

Where i represents a specific bank, $\mathrm{k}$ stands for a specific bank output, MS is the market share, while MC measures the marginal cost. $\beta$ denotes the Boone indicator. In this paper, we focus on the analysis of competition in different markets reflecting traditional loan and deposit activities as well as non-interest income generating businesses. Thus, $\mathrm{K}=$ loans, deposits, non-interest income. 
Compared to other competition indicators such as Lerner index, Panzar-Rosse H-statistic or Herfinal-Hirschman index (Birt et al., 2006), the Boone indicator has the advantages of measuring competition for several specific product markets and different categories of banks. This advantage provides more insight for future research and also provides more valuable information for government and banking regulatory authorities to make relevant policies(Tabak et al., 2012). Because the Boone indicator is time dependent, In other words, it reflects the changes in competition over time, thus, the Boone indicator will be estimated on a year by year basis. There is no benchmark for the value of beta, it is only known that the more negative of the value, the stronger competition it is.

With regard to the calculation of marginal cost, rather than using the average variable cost, we use a translog cost function to estimate it. The advantage of using the translog cost function to estimate the marginal cost lies to the fact that it allows focusing on segments of the market, such as loan market, deposit market, and non-interest income market, where no direct observations of individual cost items are available. Furthermore, rather than using the profit as the dependent variable, we use the market shares following Tabak et al. (2012). The advantage of using market share rather than profit as the dependent variable lies to the fact that the market shares are always positive while the profit values can be either positive or negative. If the log-linear specification is used, the negative profits would be excluded. In other words, the biased estimation results will be obtained due to the fact that banks with higher inefficiency and higher levels of losses would have to be ignored. 
The marginal cost is estimated on the basis of a translog cost function with four outputs (total loans, total deposits, securities and non-interest income) and two input prices (price of labour, price of capital). The specification of the translog cost function is shown as below (Tabak et al., 2012):

$L N\left(\frac{C}{W_{2}}\right)_{i t}=\delta_{0}+\sum_{j} \delta_{j} L N Y_{j i t}+\frac{1}{2} \sum_{j} \sum_{k} \delta_{j k} L N Y_{j i t} L N Y_{k i t}+\beta_{1} L N\left(\frac{W_{1}}{W_{2}}\right)_{i t}+\frac{1}{2} \beta_{11} L N\left(\frac{W_{1}}{W_{2}}\right)_{i t} L N\left(\frac{W_{1}}{W_{2}}\right)_{i t}+\sum_{j} \theta_{j} L N Y_{j i t} L N\left(\frac{W_{1}}{W_{2}}\right)_{i t}+\varepsilon_{i t}$

where $\mathrm{C}$ represents total cost of a bank, $\mathrm{Y}$ represents four outputs including total deposits, total loans, non-interest income and securities ${ }^{1}$, W stands for two input prices with $\mathrm{W} 1$ representing the price of funds, which is measured by the ratio of interest expenses to total deposits, W2 represents the price of capital, which is measured by the ratio of non-interest expenses to fixed assets, two input prices are considered due to the fact that non-interest expenses include the labour cost as well (Hasan and Morton, 2003). In other words, the price of capital considers the factors relating to the price of physical capital as well as the price of human capital. The linear homogeneity is ensured by normalizing the dependent variable and W1 by anther input price W2. The summary statistics of the variables are reported in Table 2.

<<Table 2---about here>>

The marginal cost of loans can be obtained by taking the first derivative of the dependent variable in the above equation (equation 2) in relationship to the output loans as follows:

\footnotetext{
${ }^{1}$ The selection of deposits, total loans and non-interest income as the output variables is in line with Chen et al. (2005) and Jiang et al. (2009), while total securities is defined as all securities in the trading, available for sale, held to maturity and other securities, while it does not include segregated securities or securities pledged as collateral for broker-dealers and asset managers. The selection of this variable as an output is in accordance with Tan and Floros (2013).
} 


$$
M C_{i l t}=\left(\frac{C_{i t} / W_{2}}{Y_{i l t}}\right)\left(\delta_{j=l}+2 \delta_{l l} L N Y_{i l t}+\sum_{k-1 \ldots k, k \neq l} \delta_{l k} L N Y_{i k t}+\theta_{l} L N\left(\frac{W_{1}}{W_{2}}\right)\right)
$$

The marginal costs of deposit and non-interest income can be obtained similarly by taking the first derivative of the dependent variable in the above equation (equation 2) in relationship to the outputs deposits and non-interest income as below:

$$
\begin{gathered}
M C_{i d t}=\left(\frac{C_{i t} / W_{2}}{Y_{i d t}}\right)\left(\delta_{j=d}+2 \delta_{d d} L N Y_{i d t}+\sum_{k-1 \ldots k, k \neq d} \delta_{d k} L N Y_{i k t}+\theta_{l} L N\left(\frac{W_{1}}{W_{2}}\right)\right) \\
M C_{\mathrm{int}}=\left(\frac{C_{i t} / W_{2}}{Y_{\mathrm{int}}}\right)\left(\delta_{j=n}+2 \delta_{n n} L N Y_{\mathrm{int}}+\sum_{k-1 \ldots k, k \neq n} \delta_{n k} L N Y_{i k t}+\theta_{l} L N\left(\frac{W_{1}}{W_{2}}\right)\right)
\end{gathered}
$$

As we can see from the above three equations used to estimate the marginal cost in different banking markets, all the variables are time dependent (including input prices, outputs and cost), while the constant term and the coefficients are not time dependent, they are derived from equation 2.

\subsection{Estimation of different types of efficiencies in the Chinese banking industry}

There are mainly two approaches which are widely used to estimate bank efficiency, they are: 1) Stochastic Frontier Approach (SFA); 2) Data Envelopment Analysis (DEA). The main argument of using DEA rather than SFA lies to the fact that the former works particularly well with small samples. Furthermore, DEA is able to handle multiple inputs and outputs stated in different measurement units and it does not necessitate knowledge of any functional form of the frontier (Charnes et al., 1995). Most empirical papers show that using DEA to estimate the efficient frontier can yield robust results (Seiford and Thrall, 1990). However, DEA also suffers from a number of 
disadvantages. First and foremost, DEA does not assume statistical noise, which means that the error term in the estimation is attributed to inefficiency (Sun and Chang, 2011). Therefore, the influence of a number of factors such as bad data, luck and extreme observations is accounted as inefficiency in DEA. Secondly, Sun and Chang (2011) further argue that measuring DEA in small samples is sensitive to the difference between the number of firms and the sum of inputs and outputs used. Fries and Taci (2005) argue that SFA is more appropriate over DEA in efficiency studies in developing countries where problems of measurement errors and uncertain economic environment are more likely to prevail. Therefore, the current study uses SFA to estimate cost efficiency in the Chinese banking industry.

The efficiency level can be estimated by specifying the commonly-used translog functional form for the cost function, the cost function will be the same as equation (2), while an additional equation has been added to separate the error term into two components as follows:

$\varepsilon_{i t}=v_{i t}+u_{i t}$

Where $v_{i t}$ is a two-sided normal disturbance term with zero mean and variance $\sigma_{v}^{2}$, it represents the effect of statistical noise, $u_{i t}$ is a non-negative random disturbance term capturing the effects of inefficiency. With regard to the estimation of profit efficiency and revenue efficiency, we use the same specification and just replace the dependent variable to profit and gross revenue. The profit indicator used is Return on Assets (ROA).

\subsection{Estimation on different types of risk in the Chinese banking industry}


This paper investigates different types of risk-taking behaviour in the Chinese banking industry including credit risk, liquidity risk, capital risk, as well as insolvency risk, the current paper uses relevant accounting ratios to measure the former three types of risk. To be more specific, The ratio of non-performing loans to total loans measures the credit risk, the higher figure of this ratio indicates higher credit risk, the ratio of liquid assets to total assets measures the liquidity risk, the higher figure of this ratio shows that the bank has lower liquidity risk ; the total regulatory capital ratio measures the capital risk, higher total regulatory capital ratio indicates that the bank has lower capital risk, the last type of risk-taking behaviour is insolvency risk, rather than using the accounting ratio, namely the Z-score (Iannotta et al., 2007; Liu and Wilson, 2013; Liu et al., 2013), the current study uses a translog specification to estimate the stability inefficiency (Tabak et al., 2012) which is supposed to provide more robustness results. The specification is expressed as:

$$
\begin{aligned}
& \operatorname{Ln}\left(\frac{Z-\text { score }}{W_{2}}\right)_{i t}=\delta_{0}+\sum_{j} \delta_{j} \operatorname{Ln} Y_{j i t}+\frac{1}{2} \sum_{j} \sum_{k} \delta_{j k} \operatorname{Ln} Y_{j i t} \operatorname{Ln} Y_{k i t}+\beta_{1} \operatorname{Ln}\left(\frac{W_{1}}{W_{2}}\right)_{i t}+\frac{1}{2} \beta_{2} \operatorname{Ln}\left(\frac{W_{1}}{W_{2}}\right)_{i t} \\
& +\sum_{j} \theta_{j} \operatorname{Ln} Y_{j i t} \operatorname{Ln}\left(\frac{W_{1}}{W_{2}}\right)_{i t}+v_{i t}-v_{i t}
\end{aligned}
$$

Where $\mathrm{W}$ represents input prices, there are two input prices which are the price of funds (the ratio of interest expenses to total deposits) and price of capital (the ratio of non-interest expenses to fixed assets). Y represents four outputs which are total loans, total deposits, securities and noninterest income. The sub-index $\mathrm{i}$ and $\mathrm{t}$ represent bank i operates at time $\mathrm{t}$, while $\mathrm{j}$ and $\mathrm{k}$ represent different outputs. The error term $\varepsilon_{i t}$ equals $v_{i t}-v_{i t}$. The first term $v_{i t}$ captures the random disturbance, which is assumed to be normally distributed, it represents the measurement errors and other uncontrolled factors, i.e. $v_{i t} \sim \mathrm{N}\left(0, \sigma_{v}^{2}\right)$. The second term $v_{i t}$ captures the technical and allocative inefficiency, both under managerial control, and it is assumed to be half-normally 
distributed, i. e. $v_{i t} \sim N^{+}\left(\mu_{i t}, \sigma_{v}^{2}\right)$. Higher stability inefficiency indicates higher risk while lower stability inefficiency means the risk is lower.

\subsection{Estimation on the determinants of bank profitability}

When estimating bank profitability, either measured by the ROA or NIM, a number of challenges are presented. First, it is endogeneity: more profitable banks may be able to increase their equity more easily by retaining profits. The relaxation of the perfect capital markets assumption allows an increase in capital to raise expected earnings. Besides capital risk, credit risk variable also suffers from the endogeneity issue. The endogeneity of the variables has been tested through the Sargan over-identifying test ${ }^{2}$. Another important problem is unobserved heterogeneity across banks, which may be very large in the Chinese case given differences in corporate governance. Finally, the profitability could be very persistent for Chinese banks because of political interference.

We tackle these three problems together by following the method of Tan (2016) who uses a onestep GMM system estimator to estimate profitability in the Chinese banking industry ${ }^{3}$. To be more specific, this study follows and expands the specification proposed by Tan (2016) as follows:

$$
I I_{i t}=\mathrm{C}+\delta I I_{i, t-1}+\sum_{j=1}^{j} \beta_{j} X_{i t}^{j}+\sum_{l=1}^{l} \beta_{l} X_{i t}^{l}+\sum_{m=1}^{m} \beta_{m} X_{i t}^{m}+v_{i t}+\mu_{i t}+\sum_{n=1}^{n-1} \partial_{n} Y e a r_{i}
$$

\footnotetext{
${ }^{2}$ The capital variable is instrumented using levels lagged by two year period, while the credit risk variable is instrumented using levels lagged by two year period in order to make sure there is no second order autocorrelation in the estimation.

${ }^{3}$ Judson and Owen (1999) argue that compare to the two-step GMM, one-step GMM can produce a smaller bias and a smaller standard deviation of the estimates.
} 
Where i refers to year and $\mathrm{t}$ refers to an individual bank, $I I_{i t}$ represents the profitability indicator for a specific bank at a specific year, $\mathrm{C}$ is the constant term, $I I_{i, t-1}$ is one period lagged profitability. $X_{i t}$ are determinants of bank profitability. They are grouped into bank-specific determinants including credit risk, liquidity risk, capital risk, insolvency risk, bank size, efficiency and bank diversification $X_{i t}^{j}$; industry-specific determinants including competition in different banking markets, stock market development and banking sector development $X_{i t}^{l}$; and macroeconomic determinants including inflation and GDP growth $X_{i t}^{m}$. Finally, we control time dummy effects from 2003-2016, which are represented by $Y_{e a r}$. The unobserved bank-specific effect and the

idiosyncratic error are represented by $v_{i t}$ and $\mu_{i t}$, respectively. $\beta_{j}, \beta_{l}$, and $\beta_{m}$ are the coefficients to be estimated, while $\delta$ represents the speed of adjustment to equilibrium. Its value ranges from 0 to 1 , with a higher figure representing slower adjustment and less competitive structure, while a lower figure indicates that there is a stronger competitive condition and a higher speed of adjustment.

\subsection{Data}

Our sample consists of data from five SOCBs, twelve JSCBs, and eighty-three CCBs. The sample covers the period 2003-2017 and the bank-specific data is collected from the following resources: 1) Bankscope database produced by Bureau Van Dijk (www.bvdinfo.com); 2) FitchConnect databased (www.fitchsolutions.com/fitch-connect); 3) annual bank financial statement. The industry-specific and macroeconomic variables are retrieved from the website of China Banking Regulatory Commission (www.cbrc.gov.cn) and the World Bank database (data.worldbank.org). 
We use two different profit measures which are ROA (Pathan et al., 2007) and NIM (Tan, 2016). The bank-specific determinants of profitability include credit risk, liquidity risk, capital risk ${ }^{4}$, insolvency risk, bank size, bank diversification and efficiency. The industry-specific variables include competition, banking sector development and stock market development. With regards to the macroeconomic determinants, we include both annual inflation rate and annual GDP growth rate. Table 3 provides a summary of the variables used in the current study and their expected effects on bank profitability. Figure 1 presents the profitability (measured by ROA and NIM) of Chinese commercial banks over the period 2003-2017.

$$
\begin{aligned}
& \text { <<Table 3--about here>> } \\
& \text { <<Figure 1---about here>> }
\end{aligned}
$$

Table 4 shows the summary statistics of the independent variables used in the current study. The table shows that the difference in liquidity risk undertaken by Chinese commercial banks is smaller than the ones for credit risk and capital risk. The data indicates that Chinese banks have big differences in the degree of diversified activities engaged in. The statistics show further that there is a stronger volatility with regard to the stock market development than of the banking sector development and the macroeconomic environment.

<<Table 4---about here>>

\footnotetext{
${ }^{4}$ We use the total regulatory capital ratio as the measurement of this risk, it is calculated by dividing the total capital (tier 1 capital and tier 2 capital) by the risk-weighted assets. It was used as an accurate measure of capital risk by the empirical literature (Tan, 2018, Tan and Floros, 2018).
} 


\section{Empirical Results}

\subsection{Efficiency in the Chinese banking industry}

Figure 2 shows the results with regard to the cost, revenue and profit efficiencies in the Chinese banking industry on an annual basis. The findings show that cost efficiency of Chinese commercial banks is more stable over the examined period compared to revenue efficiency, while it is found that Chinese commercial banks have the strongest volatility in profit efficiency.

<<Figure 2---about here >>

\subsection{Competitive condition in different banking markets in China}

Figure 3 shows the competitive conditions in different banking markets (loan market, deposit market and non-interest income market) in China over the period 2003-2017. The finding shows that the competition among Chinese commercial banks in the loan market, deposit market and non-interest income market is relatively stronger over the period 2003-2005, while the competition over the period 2006-2013 is lower. It is noticed that during 2014-2017, the competition in the Chinese banking industry increases significantly. We attribute this finding to the effectiveness of interest rate liberalization in China. The figure shows that the competitive condition in the non-interest income market is the highest in general during 2003-2015 and between 2014-2017 compared to the other two markets, while the competitive conditions in the loan market and the deposit market are the same especially during the period 2006-2013. The results are partly in line with Tan (2017), Wang and Wang (2016). Our Boone indicator results are different from the ones reported by the Federal Reserve Bank of St. Louis. However, we believe our estimation provides more robust results due to the fact that rather than using average 
cost as a proxy of marginal cost, we use a translog cost function. We also use market share rather than profits as the dependent variable in the estimation of Boone indicator due to the fact negative profits would be excluded if a log-linear specification is used as discussed in our paper. Our estimation is also better because we cover competition conditions in different banking markets (loan market, deposit market and non-interest income market) rather than purely estimating the competition of profit efficiency.

$<<$ Figure 3---about here >>

\subsection{Risk conditions in the Chinese banking industry}

Figure 4 shows the risk conditions in the Chinese banking industry as measured by credit risk, liquidity risk, capital risk and insolvency risk over the period 2003-2017. It is clearly indicated by the figure that liquidity risk and insolvency risk are quite stable over the period, however, the credit risk has been declining consistently but with the strongest volatility. We also notice that capital risk is more volatile compared to liquidity risk and insolvency risk.

$<<$ Figures 4---about here >>

\subsection{The impacts of efficiency, risk and competition on profitability}

Before proceeding to the estimation with regard to the impacts of efficiency, risk and competition on bank profitability in China, the multicollinearity test has been conducted to check whether there is any multicollinearity issue among the explanatory variables. The results of the test show that 
there is no multicollinearity issue among the variables ${ }^{5}$. Table 5 shows the results with regard to the impacts of risk, efficiency and competition in different banking markets on bank profitability in China. The F statistic shows that the variables in the model are jointly significant while the Sargan test statistic shows that there are no over-identified restrictions. The results further indicate that the first-order autocorrelation is present for all the cases, while the second-order autocorrelation is rejected, which guarantees the consistency of the results. The finding shows that the lag of the dependent variable (both ROA and NIM) are significant and positive, which indicates that the dynamic specification of the model is correct, while the significant and positive signs of the lagged dependent variables further suggest that the profitability of Chinese commercial banks in the current year is significantly and positively affected by its previous year's profitability.

With regard to the bank-specific determinants of profitability, the results report that liquidity risk is significantly and positively related to ROA, indicating that Chinese commercial banks with higher levels of liquidity (lower levels of liquidity risk) have lower profitability. This is in consistent with the findings of Molyneux and Thornton (1992).

The results indicate that bank size is significantly and negatively related to bank profitability. This result is in accordance with the finding of Goddard to al. (2001). However, this is in contract with our hypothesis as reflected from Table 3 . The negative impact of size on bank profitability can be explained by the fact that large banks are difficult to be managed (Tan and Floros, 2012a), which induces a larger amount of efforts, the resulted increase in the cost leads to a decline in bank profitability.

\footnotetext{
${ }^{5}$ The results are not reported in the current paper, however, it is available from the author upon request.
} 
Cost efficiency is found to be significantly and positively related to bank profitability, indicating that Chinese commercial banks with higher levels of cost efficiency have higher profitability. This result is in line with the finding of Tan and Floros (2012b). The profit efficiency is found to be significantly and positively related to profitability of Chinese commercial banks, indicating that Chinese commercial banks with higher levels of profit efficiency have higher profitability.

The findings suggest that Chinese commercial banks with a higher degree of business diversification have lower NIM. Our finding is different from the hypothesis we made as reflected in Table 3. NIM concentrates on interest-generating activities only. Our results underline that Chinese commercial banks with more diversified businesses can generate higher income, while more resources/funds used in engaging in the non-interest generating businesses reduces the volumes of traditional loan business, which further proceeds a decrease in NIM of Chinese commercial banks.

Banking sector development is found to be significantly and positively related to bank profitability (ROA). This can be explained by the fact that in a higher developed banking market, there will be a higher volume of demand for banking products (Tan and Floros, 2012a). This result indicates that there will be a significant increase in the demand of non-interest generating businesses in a higher developed banking market, which proceeds a significant increase in ROA but not NIM.

Finally, with regard to the macroeconomic determinants of bank profitability, the findings suggest that Chinese commercial banks have higher profitability in terms of ROA and NIM in a higher inflationary environment. The higher inflationary environment is associated with higher loan interest rate, which will increase bank profitability (Tan and Floros, 2012a). In theory, this result 
indicates that Chinese commercial banks have the ability to anticipate the interest rate and adjust the interest rate accordingly (Perry, 1992).

$$
<<\text { Table 5---about here >> }
$$

\section{Robustness check and additional tests}

\subsection{Robustness check}

We have done a series of additional tests to check the robustness of our results. Firstly, regarding the measurement of competition in different banking markets, we use Hirfindahl-Hirsmann index to evaluate the level of competition in deposit market, loan market and non-interest income market further test their impacts on bank profitability. Secondly, rather than using the stochastic frontier analysis to estimate different types of efficiencies, we use the non-parametric data envelopment analysis to evaluate profit, cost and revenue efficiencies. We also use alternative indicators to measure different types of risk. To be more specific, we use the ratio of loan loss provision to total loans to measure credit risk, the liquidity risk is cross checked by using the ratio of loans to total assets, the capital risk is alternatively measured by the ratio of shareholders' equity to total assets, while Z-score is used as an alternative measure of insolvency risk. We use these alternative measures of different types of risk to double check the robustness of our results. The results of the above robustness checks are reported in Table 6, 7, and 8, respectively. As we can see from the tables, the results hold compared to the original estimation.

<<Table 6-8----about here〉> 
Not only do we focus on using alternative methods to measure the key variables, we also use subperiods and subsamples under different econometric techniques to check the robustness of our findings. Firstly, we divide our sample period into two sub-periods with either one covering the years of financial crisis. In other words, we divide our sample into:1) 2003-2009 and 2010-2013; 2) 2003-2006 and 2007-2013. Besides using sub-periods, we also use sub-samples to see whether our findings holds. More specially, we divide the whole sample into three sub-samples according to the ownership types (SOCBs, JSCBs and CCBs). We test the joint-impacts of competition in different banking markets, different types of risk and efficiencies on bank profitability for each of these three ownership types. Due to the fact that we have limited number of observations especially for SOCBs, which makes the estimation under GMM impossible, therefore, we use an alternative econometric method (fixed effect) to estimate the joint impacts. The use of this alternative econometric method provides further robustness check of our findings. The results of the above tests are reported in Table 9, 10 and 11. Regarding the robustness test using different sub-periods as reported in Table 9 and Table 10, the results that they are quantitatively similar with the original estimation, while in addition to the original results, we find that credit risk and capital risk are significantly related to bank profitability in China. In terms of the estimation on different ownership types of Chinese commercial banks, as reported in Table 11, we notice that the findings are partly in line with the whole sample, which shows that the profitability in the Chinese banking industry is affected by size, diversification, banking sector development and inflation. We additionally find out that a lower competitive loan market will lead to an improvement in profitability for all three different ownership types of Chinese banks.

<<Table 9-11---about here>> 


\subsection{Additional tests}

As indicated in the Introduction, our paper contribute to the empirical banking literature by testing and comparing the impact of efficiency on profitability when banks undertake different levels of risk and face different degrees of competition. We report the test results of these in Table 12, 13 and 14 . When testing the impact of efficiency on profitability when banks face different levels of competition, as reported in Table 12, it shows that some key significant variables still show the same sign compared to the original estimation, such as bank size, bank diversification, banking sector development and inflation, while it is noticed that the sign of cost efficiency is consistently significant and positive across the table, showing that cost efficiency improvement will have a positive impact on bank profitability. Furthermore, we find that the impact of cost efficiency on bank profitability is stronger when banks face higher levels of competition. This can be explained by the fact that in a higher level of competitive environment, banks normally spend more resources and take more efforts in order to expand the business and enhance the risk management, larger amount of costs and wastes is expected, a slight improvement in resource allocation is supposed to lead to a significantly improvement in bank cost and further result in an improvement in bank profitability.

Regarding the impact of efficiency on profitability when banks undertake different level of risktaking behavior, the results of which are reported in Table 13 (for credit risk and liquidity risk) and 14 (capital risk and insolvency risk), it shows that bank size, banking sector development and inflation are significantly related to bank profitability in China, which is in line with our original estimation. In addition, we find from this additional test that the same as the estimation for different ownership types of Chinese banks, lower level of competition in the loan market leads to an 
improvement in bank profitability in China. Finally, the findings suggest that the cost efficiency is significantly and positively related to bank profitability consistently across the table, while stronger effect is shown for the banks undertaking higher levels of risk. This finding can be explained by the fact that higher levels of risk will incur larger amount of expenses and costs (write-off the non-performing loans, use additional resources to monitor risk, etc), which significantly reduces bank profitability, if the banks can optimize the resource, this will offset partly or wholly the extra expenses or costs incurred and further lead to an improvement in bank profitability.

$<<$ Table 12-14---about here〉>

\section{Conclusion}

This study uses a sample of Chinese commercial banks (SOCBs, JSCBs and CCSs) over the period 2003-2017 to test the impact of competition in different banking markets (deposit market, loan market and non-interest income market), different types of efficiencies and different types of risk on bank profitability. Our paper significantly contribute to the empirical banking literature by testing and comparing the impact of efficiency on profitability when bank undertake different levels of risk and face different degrees of competition. Also our results are robust through a serious of alternative tests.

The findings suggest that bank size is significantly and negatively related to bank profitability in China, while industry and macroeconomic environment are also play an important role in determining bank profitability in China such as banking sector development and inflation. In addition, the results show that there is a significant and positive impact of cost efficiency on bank 
profitability. Finally, we find that the impact of efficiency on profitability in stronger when banks undertake higher levels of risk and face higher degrees of competition.

The results of the current paper provides important implications to Chinese government as well as banking regulatory authorities to make relevant policies to reform the banking sector and further improve the bank performance as follows: 1) large banks need to formulate a better management system; simplified working culture is supposed to improve bank profitability ;2) relevant policies should be made to further inprove the development of banking industry in the economy and the macroeconomic environment needs to be considered and coordinated between increase in the inflation level and increase in bank profitability; 3) Chinese banks should find ways to improve the resource allocation and further reduce the cost in the process of bank production.

\section{References:}

Angbanzo, L. (1997). Commercial bank net interest margins, default risk, interest-rate risk and off-balance sheet banking. Journal of Banking and Finance, 21, 55-87.

Berger, A. N. 1995. The Profit-Structure Relationship in Banking-Test of Market-Power and Efficient-Structure Hypotheses. Journal of Money, Credit and Banking, 27, 404-431.

Birt, J. L., Bilson, C. M., Smith, T., \& Whaley, R. E. (2006). Ownership, Competition and Financial Disclosure. Australian Journal of Management, 31, 235-263.

Boone, J. (2008). A new way to measure competition. The Economic Journal, 118, 1245-1261. 
Charnes, A., Cooper, W. W., Lewin, A. Y., \& Seiford, L. M. (1995). Data Envelopment Analysis: Theory, methodology and applications. Boston: Kluwer.

Claeys, S., \& Vennet, R.V. (2008). Determinants of bank interest margins in central and Eastern Europe: a comparison with the west. Economic Systems, 32, 197-216.

Chen, X., Skully, M., and Brown, K. (2005). Bank efficiency in China: Application of DEA to pre- and post-deregulation ears: 1993-2000. China Economic Review, 16, 229-245.

Demsetz, H. (1973). Industry structure, market rivalry and public policy. Journal of Law and Economics, 16, 1-19.

Fries, S., \& Taci, A. (2005). Cost Efficiency of Banks in Transition: Evidence from 289 Banks in 15 Post Communist Countries. Journal of Banking and Finance, 29, 55-81.

Garcia-Herrero, A., Gavila, S., \& Santabarbara, D. 2009. What explains the low profitability of Chinese banks? Journal of Banking and Finance, 33, 2080-2092.

Goddard, J. A., Molyneux, P., \& Wilson, J. (2001). European banking: efficiency, technology and growth. Chichester: Wiley.

Hasan, I., \& Morton, K. (2003). Development and efficiency of the banking sector in a transitional economy: Hungarian experience. Journal of Banking and Finance, 27, 2249-2271.

Heffernan, S., \& Fu, M. (2010). Determinants of financial performance in Chinese banking. Applied Financial Economics, 20, 1585-1600. 
Iannotta, G., Nocera, G., \& Sironi, A. (2007). Ownership structure, risk and performance in the European banking industry. Journal of Banking and Finance, 31, 2127-2149.

Jiang, C., Yao, S., and Zhang, Z. (2009). The effects of governance changes on bank efficiency in China: A stochastic distance function approach. China Economic Review, 20, 717-731.

Judson, R. A., \& Owen, A. L. (1999). Estimating dynamic panel data models: a guide for macroeconomists. Economics Letters, 65, 9-15.

Liu, H., \& Wilson, J. (2013). Competition and risk in Japanese banking. European Journal of Finance, 19, 1-18.

Liu, H., Molyneux, P., \& Wilson, J. (2013). Competition and stability in European banking: a regional analysis. The Manchester School, 81, 176-201.

Maudos, J., \& Fenandez de Guevara, J. (2004). Factors explaining the interest margin in the banking sectors of the European Union. Journal of Banking and Finance, 28, 2259-2281.

Molyneux, P., \& Thornton, J. (1992). Determinants of European bank profitability: A Note. Journal of Banking and Finance, 16, 1173-1178.

Panthan, S., Skully M., \&Wickramanayake, J. (2007). Board Size, Independence and Performance: An Analysis of Thai Banks. Asia-Pacific Financial Markets, 14, 211-227.

Perry, P. (1992). Do banks gain or lose from inflation? Journal of Retail Banking, 14, 25-30.

Seiford, L. M., \& Thrall, R. M. (1990). Recent development in DEA: The mathematical programming approach to frontier analysis. Journal of Econometrics, 46, 7-38. 
Shih, V., Zhang, Q., \& Liu, M. (2007). Comparing the performance of Chinese banks: a principle component approach. China Economic Review, 18, 15-34.

Sufian, F. (2009). Determinants of Bank profitability in a Developing Economy: Empirical evidence from the China Banking Sector. Journal of Asia-Pacific Business, 10, 201-307.

Sufian, F., \& Habibullah M. S. (2009). Bank specific and macroeconomic determinants of bank profitability: Empirical evidence from the China Banking Sector. Frontier of Economics in China, 4, 274-291.

Sun, L., \& Chang T. (2011). A comprehensive analysis of the effects of risk measures on bank efficiency: Evidence from Emerging Asian countries. Journal of Banking and Finance, 35, 17271735.

Tabak, B. M., Fazio, D. M., \& Cajueiro, D. O. (2012). The relationship between banking market competition and risk-taking: Do bank size and capitalization matter? Journal of Banking and Finance, 36, 3366-3381.

Tan, Y., \& Floros, C. (2012a). Bank profitability and inflation: the case of China. Journal of Economic Studies, 39, 675-696.

Tan, Y., \& Floros, C. (2012b). Bank profitability and GPD growth in China: a note. Journal of Chinese Economics and Business Studies, 10, 267-273.

Tan, Y., \& Floros, C. (2012c). Stock market volatility and bank performance in China. Studies in Economics and Finance, 29, 211-228. 
Tan, Y., and Floros, C. (2013). Risk, capital and efficiency in Chinese banking. Journal of International Financial Markets, Institutions and Money, 26, 378-393.

Tan, Y. (2016). The impacts of risk and competition on bank profitability in China. Journal of International Financial Markets, Institutions and Money, 40, 85-110.

Tan, Y., \& Floros, C. (2014). Risk, profitability and competition: evidence from the Chinese banking. Journal of Developing Areas, 48, 303-319.

Tan, Y. (2017). The impacts of competition and shadow banking on profitability: Evidence from the Chinese banking industry. The North American Journal of Economics and Finance, 42, 89106.

Tan, Y., Floros, C., and Anchor, J. (2017). The profitability of Chinese banks: impacts of risk, competition and efficiency. Review of Accounting and Finance, 16, 86-105.

Tan, Y. (2018). The impacts of competition and risk on profitability in Chinese banking: evidence from Boone indicator and stability inefficiency. Annals of Economics and Finance, 19, $523-554$.

Tan, Y., and Floros. (2018). Risk, competition and efficiency in banking: Evidence from China. Global Finance Journal, 35, 223-236.

Wang, G., and Wang, Q. (2016). Research on the relationship between market power and stability in the Chinese banking industry: evidence from Boone indicator. Economic Review, 1, $117-131$. 
Table 1 Summary of the assets of SOCBs, JSCBs, CCBs and total banking institutions in China over the period 2003-2013

\begin{tabular}{|c|c|c|c|c|c|c|c|c|c|c|c|c|c|c|c|}
\hline & 2003 & 2004 & 2005 & 2006 & 2007 & 2008 & 2009 & 2010 & 2011 & 2012 & 2013 & 2014 & 2015 & 2016 & 2017 \\
\hline SOCBs & $\begin{array}{l}160512 \\
(58.03 \%)\end{array}$ & $\begin{array}{l}179817 \\
(56.9 \%)\end{array}$ & $\begin{array}{l}210050 \\
(56.1 \%)\end{array}$ & $\begin{array}{l}242364 \\
(55.2 \%)\end{array}$ & $\begin{array}{l}285000 \\
(53.7 \%)\end{array}$ & $\begin{array}{l}325751 \\
(51.59 \%)\end{array}$ & $\begin{array}{l}407998 \\
(51.31 \%)\end{array}$ & $\begin{array}{l}468943 \\
(49.2 \%)\end{array}$ & $\begin{array}{l}536336 \\
(47.34 \%)\end{array}$ & $\begin{array}{l}600401 \\
(52.84 \%)\end{array}$ & $\begin{array}{l}656005 \\
(43.34 \%)\end{array}$ & $\begin{array}{l}710141 \\
(41.21 \%)\end{array}$ & $\begin{array}{l}781630 \\
(39.21 \%)\end{array}$ & $\begin{array}{l}865982 \\
(37.29 \%)\end{array}$ & $\begin{array}{l}928145 \\
(36.77 \\
\%)\end{array}$ \\
\hline JSCBs & $\begin{array}{l}29599 \\
(10.7 \%)\end{array}$ & $\begin{array}{l}36476 \\
(11.5 \%)\end{array}$ & $\begin{array}{l}44655 \\
(11.92 \%)\end{array}$ & $\begin{array}{l}54446 \\
(12.4 \%)\end{array}$ & $\begin{array}{l}72742 \\
(13.69 \%)\end{array}$ & $\begin{array}{l}88337 \\
(13.99 \%)\end{array}$ & $\begin{array}{l}118181 \\
(14.86 \%)\end{array}$ & $\begin{array}{l}149037 \\
(15.64 \%)\end{array}$ & $\begin{array}{l}183794 \\
(16.22 \%)\end{array}$ & $\begin{array}{l}235271 \\
(20.71 \%)\end{array}$ & $\begin{array}{l}269361 \\
(17.8 \%)\end{array}$ & $\begin{array}{l}313801 \\
(18.21 \%)\end{array}$ & $\begin{array}{l}369880 \\
(18.55 \%)\end{array}$ & $\begin{array}{l}434732 \\
(18.72 \%)\end{array}$ & $\begin{array}{l}449620 \\
(17.81 \\
\%)\end{array}$ \\
\hline CCBs & $\begin{array}{l}14622 \\
(5.3 \%)\end{array}$ & $\begin{array}{l}17056 \\
(5.4 \%)\end{array}$ & $\begin{array}{l}20367 \\
(5.44 \%)\end{array}$ & $\begin{array}{l}25938 \\
(5.9 \%)\end{array}$ & $\begin{array}{l}3405 \\
(6.29 \%)\end{array}$ & $\begin{array}{l}41320 \\
(6.54 \%)\end{array}$ & $\begin{array}{l}56800 \\
(7.14 \%)\end{array}$ & $\begin{array}{l}78526 \\
(8.24 \%)\end{array}$ & $\begin{array}{l}99845 \\
(8.81 \%)\end{array}$ & $\begin{array}{l}123469 \\
(10.87 \%)\end{array}$ & $\begin{array}{l}151778 \\
(10.03 \%)\end{array}$ & $\begin{array}{l}180842 \\
(10.49 \%)\end{array}$ & $\begin{array}{l}226802 \\
(11.38 \%)\end{array}$ & $\begin{array}{l}282378 \\
(12.16)\end{array}$ & $\begin{array}{l}317217 \\
(12.57 \\
\%)\end{array}$ \\
\hline $\begin{array}{l}\text { Banking } \\
\text { institutions }\end{array}$ & 276584 & 315990 & 374697 & 439500 & 531160 & 631515 & 795146 & 953053 & 1132873 & 1136224 & 1513547 & 1723355 & 1993454 & 2322532 & $\begin{array}{l}252404 \\
0\end{array}$ \\
\hline
\end{tabular}

- Source: China Banking Regulatory Commission annual statements 2003-2017, total assets are expressed in RMB 100 million. 
Table 2 Summary statistics

\begin{tabular}{|l|l|l|l|l|l|}
\hline Variables & Observations & Mean & S.D & Min & Max \\
\hline $\begin{array}{l}\text { Total cost } \\
\text { interest } \\
\text { expenses and } \\
\text { non-interest } \\
\text { expenses) }\end{array}$ & 1200 & 388574 & 0.97 & 216752 & 498715 \\
\hline $\begin{array}{l}\text { Price of funds } \\
\text { (the ratio of } \\
\text { interest } \\
\text { expenses to } \\
\text { total deposits) }\end{array}$ & 1200 & 0.018 & 0.23 & 0.014 & 0.027 \\
\hline $\begin{array}{l}\text { Price of capital } \\
\text { (the ratio of } \\
\text { non-interest } \\
\text { expenses to } \\
\text { fixed assets) }\end{array}$ & 1200 & 1.27 & 0.35 & 1.03 & 1.33 \\
\hline Total loans & 1200 & 11195832 & 0.1 .35 & 4238980 & 19032627 \\
\hline Securities & 1200 & 8201634 & 1.39 & 1818083 & 12903441 \\
\hline $\begin{array}{l}\text { Non-interest } \\
\text { income }\end{array}$ & 1200 & 3894792 & 1.69 & 1059406 & 5271695 \\
\hline Total deposits & 1200 & 23485719 & 1.81 & 36356 & 143884 \\
\hline
\end{tabular}

- Total cost, total loans, securities, non-interest income and total deposits are in RMB 100 million, while price of funds and price of capital are in the form of ratios 
Table 3 Description of the variables and their impact on bank profitability

\begin{tabular}{|c|c|c|c|}
\hline Variables & Measurement & Expected effect & Source \\
\hline \multicolumn{4}{|l|}{$\begin{array}{l}\text { Profitability } \\
\text { indicators }\end{array}$} \\
\hline ROA & $\begin{array}{l}\text { Net income/total } \\
\text { assets }\end{array}$ & & Bankscope \\
\hline NIM & $\begin{array}{l}\text { Net interest } \\
\text { income/earning assets }\end{array}$ & & Bankscope \\
\hline \multicolumn{4}{|l|}{$\begin{array}{l}\text { Bank-specific } \\
\text { variables }\end{array}$} \\
\hline Credit risk & $\begin{array}{l}\text { impaired loans/gross } \\
\text { loans }\end{array}$ & - & Bankscope \\
\hline Liquidity risk & $\begin{array}{l}\text { liquid assets/total } \\
\text { assets }\end{array}$ & $?$ & Bankscope \\
\hline Capital risk & $\begin{array}{l}\text { Total regulatory } \\
\text { capital ratio }\end{array}$ & $?$ & Bankscope \\
\hline Insolvency risk & stability inefficiency & - & Bankscope \\
\hline bank size & $\begin{array}{l}\text { natural logarithm of } \\
\text { total assets }\end{array}$ & + & Bankscope \\
\hline Bank diversification & $\begin{array}{l}\text { Non-interest } \\
\text { income/gross revenue }\end{array}$ & + & Bankscope \\
\hline Cost efficiency & \multirow{3}{*}{$\begin{array}{l}\text { Derived from } \\
\text { Stochastic frontier } \\
\text { analysis }\end{array}$} & \multirow[t]{3}{*}{$?$} & Banksocpe \\
\hline Profit efficiency & & & \\
\hline Revenue efficiency & & & \\
\hline \multicolumn{4}{|l|}{$\begin{array}{l}\text { Industry-specific } \\
\text { variables }\end{array}$} \\
\hline Bank competition & Boone indicator & $?$ & \\
\hline $\begin{array}{l}\text { Banking sector } \\
\text { development }\end{array}$ & $\begin{array}{l}\text { Banking sector } \\
\text { assets/GDP }\end{array}$ & + & $\begin{array}{l}\text { China Banking } \\
\text { Regulatory } \\
\text { Commission }\end{array}$ \\
\hline $\begin{array}{l}\text { Stock market } \\
\text { development }\end{array}$ & $\begin{array}{l}\text { Market capitalization } \\
\text { of listed } \\
\text { companies/GDP }\end{array}$ & + & World Bank \\
\hline \multicolumn{4}{|l|}{$\begin{array}{l}\text { Macroeconomic } \\
\text { variables }\end{array}$} \\
\hline Inflation & Annual inflation rate & $?$ & World Bank \\
\hline GDP growth & $\begin{array}{l}\text { Annual GDP growth } \\
\text { rate }\end{array}$ & - & World Bank \\
\hline
\end{tabular}


Figure 1 The profitability in the Chinese banking industry during 2003-2017

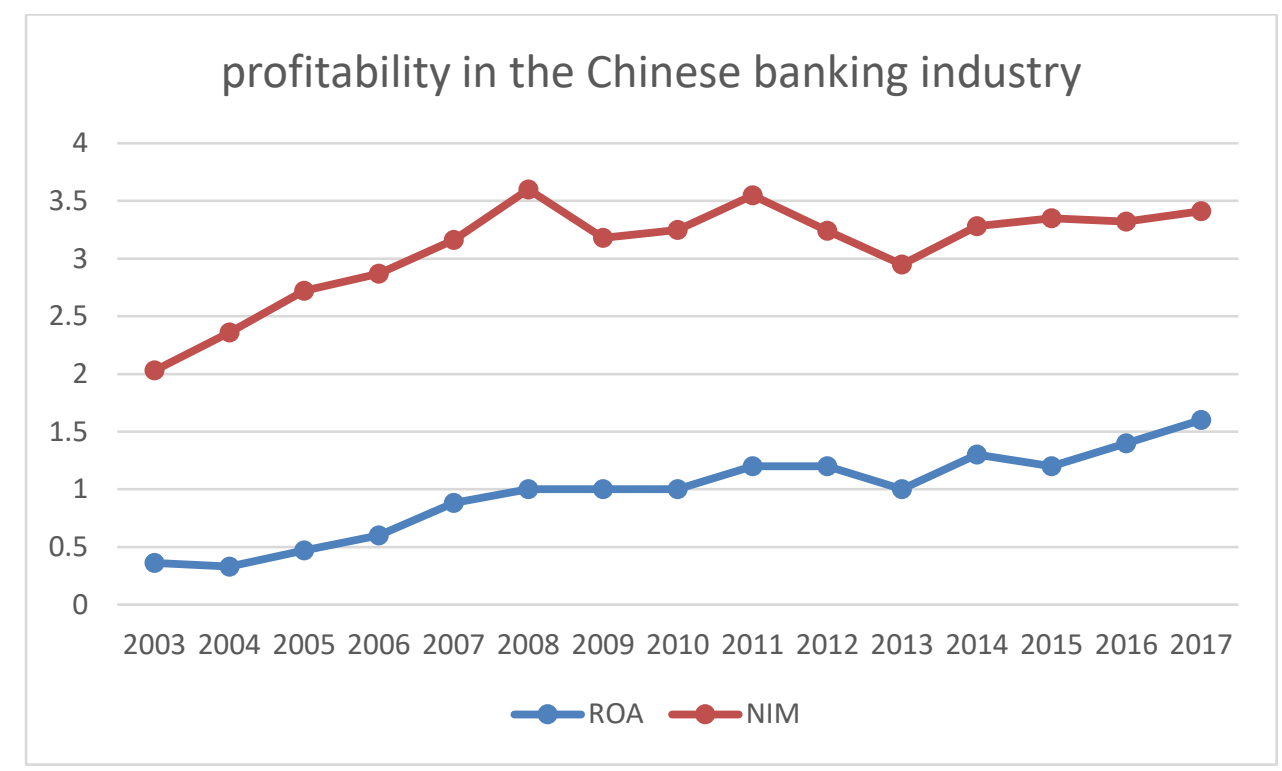


Table 4 Descriptive statistics of all variables considered in this study

\begin{tabular}{|l|l|l|l|l|l|}
\hline Variables & Observations & Mean & S.D & Min & Max \\
\hline Credit risk & 1200 & 2.78 & 4.48 & 0 & 41.86 \\
\hline Liquidity risk & 1200 & 0.22 & 0.13 & 0.02 & 0.88 \\
\hline Capital risk & 1200 & 14.48 & 5.1 & 0.62 & 73.57 \\
\hline Insolvency risk & 1200 & 0.52 & 0.38 & 0.025 & 0.915 \\
\hline Bank size & 1200 & 6.6 & 1.25 & 0.71 & 10.09 \\
\hline $\begin{array}{l}\text { Bank } \\
\text { diversification }\end{array}$ & 1200 & 20.04 & 16.13 & -12.94 & 91.29 \\
\hline $\begin{array}{l}\text { Banking sector } \\
\text { development }\end{array}$ & 1200 & 3.77 & 0.29 & 1.98 & 4.82 \\
\hline $\begin{array}{l}\text { Stock market } \\
\text { development }\end{array}$ & 1200 & 80.08 & 48.94 & 31.9 & 225.63 \\
\hline $\begin{array}{l}\text { Inflation } \\
\text { GDP growth } \\
\text { rate } 1200\end{array}$ & 1200 & 2.61 & 1.75 & -0.73 & 5.925 \\
\hline
\end{tabular}

- all the bank specific and industry specific variables are in the form of a ratio, while the macroeconomic environment is in the form of percentage. 
Figure 2 Cost, revenue and profit efficiencies of Chinese commercial banks on annual basis

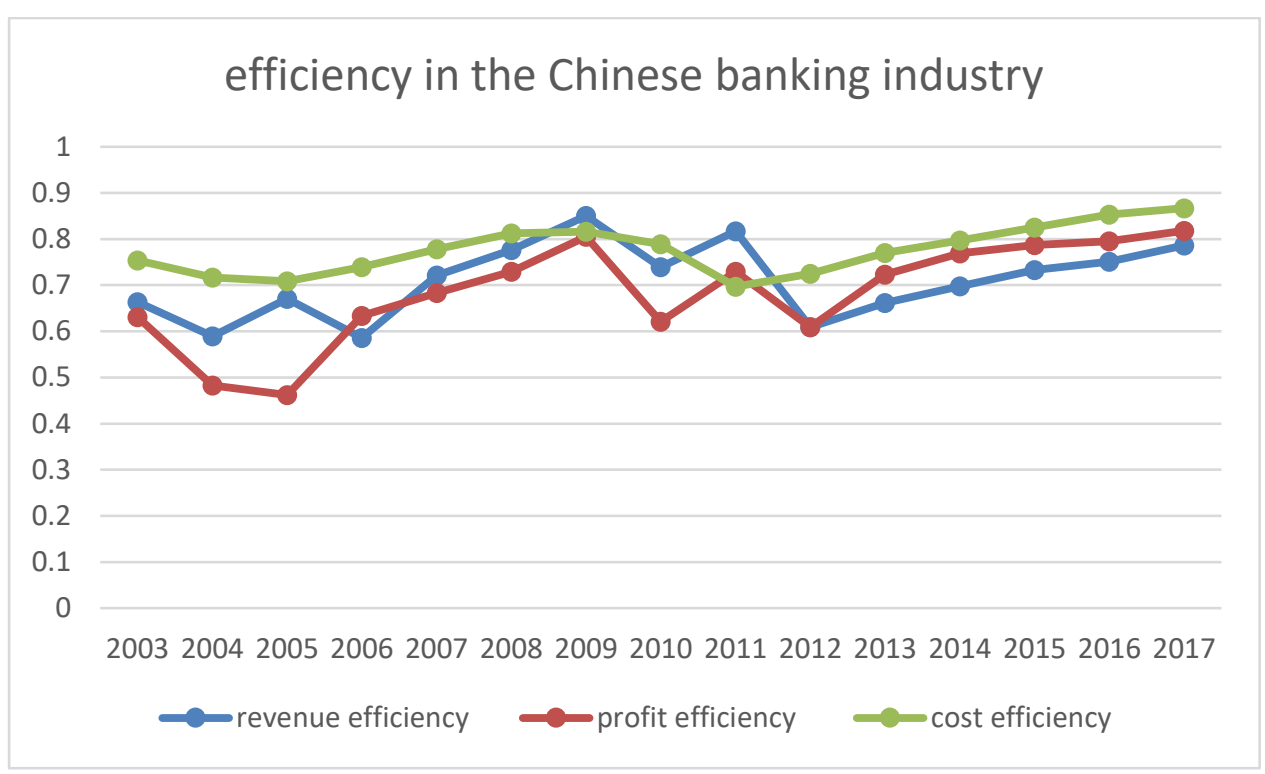


Figure 3 Competition in different banking markets over the period 2003-2013

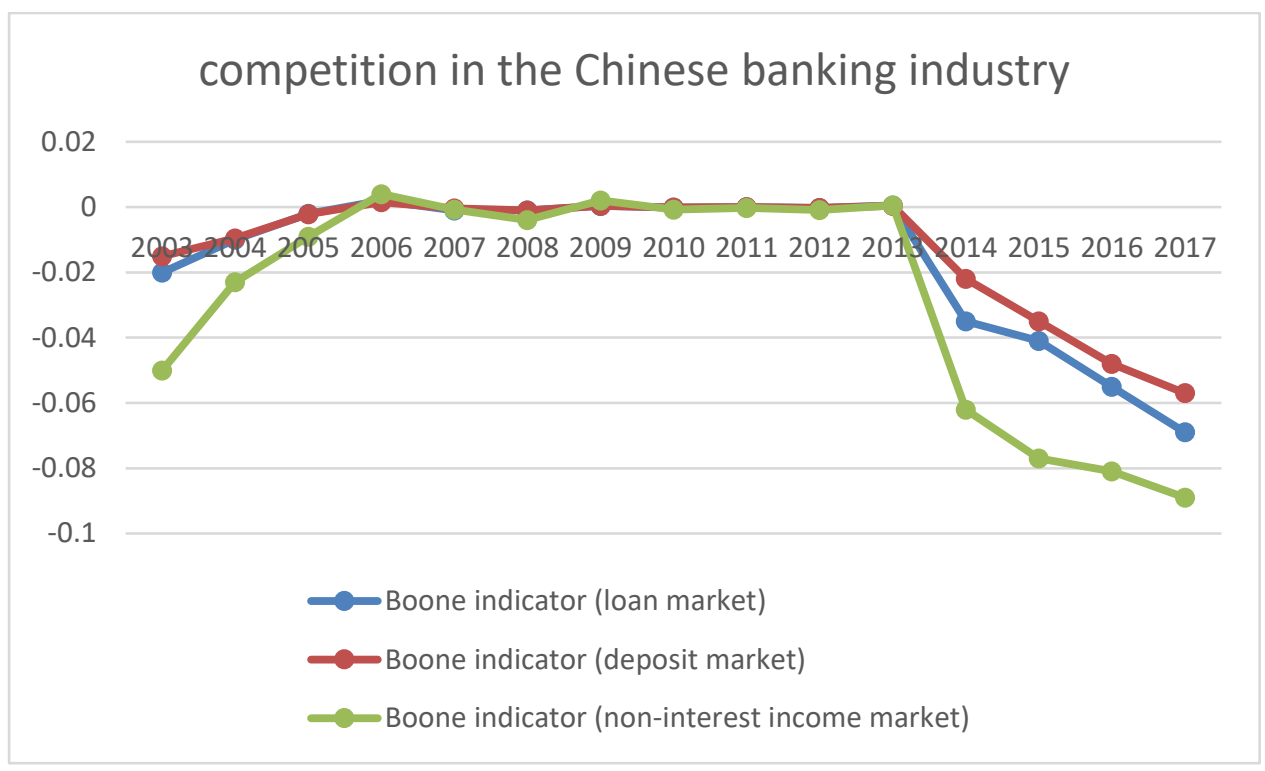


Figure 4 Risk conditions in the Chinese banking industry: 2003-2013

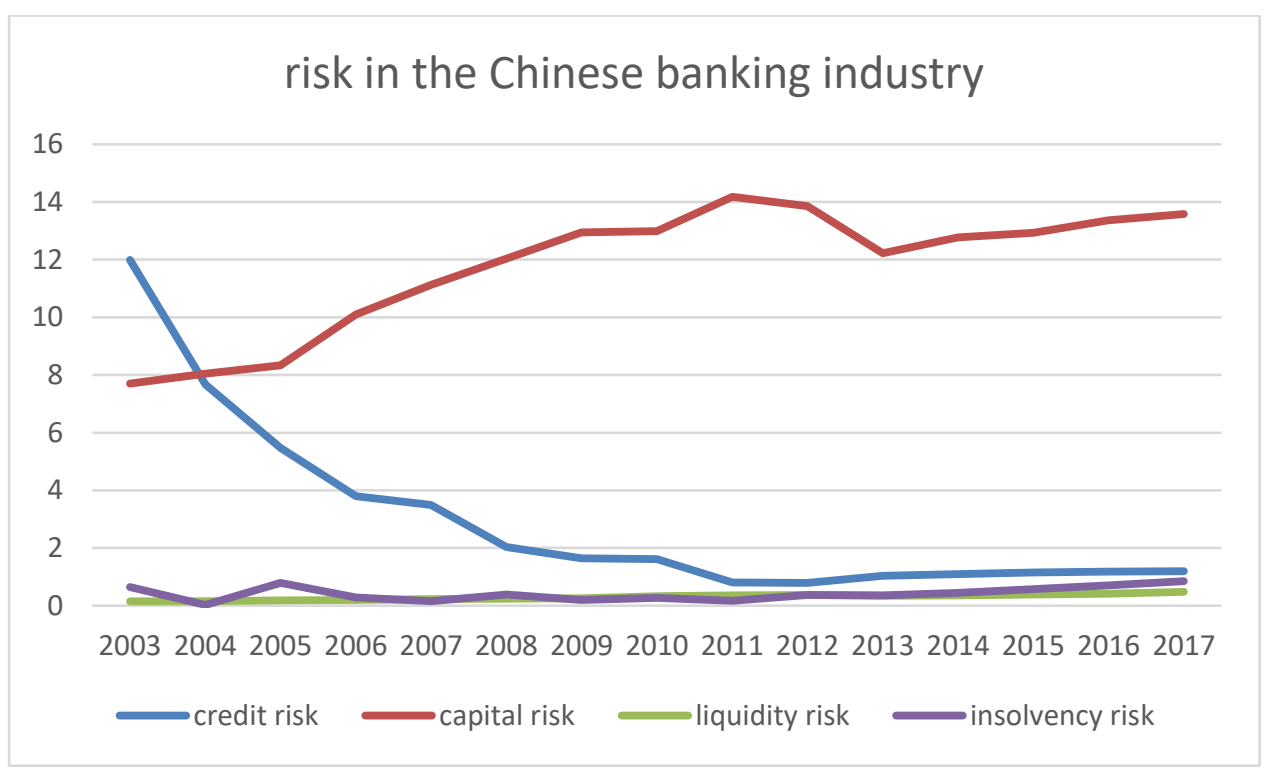


Table 5 Empirical results: The impacts of risk, efficiency and competition on bank profitability

\begin{tabular}{|c|c|c|c|c|}
\hline & \multicolumn{2}{|l|}{ ROA } & \multicolumn{2}{|l|}{ NIM } \\
\hline & coefficient & t-statistic & Coefficient & t-statistic \\
\hline Lag of dependent variable & $0.21 * *$ & 2.27 & $0.39 * * *$ & 5.83 \\
\hline \multicolumn{5}{|l|}{ Bank characteristics } \\
\hline Credit risk & -0.001 & -0.59 & 0.12 & 1.15 \\
\hline Liquidity risk & $-0.23 * *$ & -2.65 & -0.38 & -1.29 \\
\hline Capital risk & -0.0005 & -0.11 & $0.19 * *$ & 2.73 \\
\hline Insolvency risk & 0.09 & 1.31 & 0.02 & 0.15 \\
\hline Bank size & $-0.007 * *$ & -2.69 & $-0.25 * * *$ & -3.23 \\
\hline Cost efficiency & $0.05 * *$ & 2.87 & $3.98 * *$ & -2.74 \\
\hline Revenue efficiency & 0.01 & 0.29 & -0.41 & -0.52 \\
\hline Profit efficiency & $0.03 * *$ & 2.47 & $3.18 * *$ & 2.29 \\
\hline Bank diversification & 0.003 & 0.71 & $-0.09 * * *$ & -8.37 \\
\hline \multicolumn{5}{|l|}{ Industry characteristics } \\
\hline Boone indicator (loan) & 2.14 & 0.52 & 5.93 & 1.17 \\
\hline Boone indicator (deposit) & -7.46 & -0.17 & -6.55 & -0.27 \\
\hline $\begin{array}{l}\text { Boone indicator (non- } \\
\text { interest income) }\end{array}$ & 1.94 & 0.65 & -93.16 & -0.56 \\
\hline Banking sector development & $0.08 * * *$ & 3.76 & 0.64 & 1.14 \\
\hline Stock market development & 0.005 & 0.98 & 0.03 & 0.62 \\
\hline \multicolumn{5}{|l|}{ Macroeconomics } \\
\hline Inflation & $0.011 * *$ & 2.78 & $0.11 * * *$ & 4.86 \\
\hline GDP growth rate & -0.005 & 0.55 & 0.04 & 0.37 \\
\hline Time dummy (2003) & $0.18 * * *$ & 4.92 & $0.15 * * *$ & 4.48 \\
\hline Time dummy (2004) & $0.15 * * *$ & 4.77 & $0.11 * * *$ & 4.33 \\
\hline Time dummy (2005) & $0.10^{* * *}$ & 6.19 & $0.08 * * *$ & 5.13 \\
\hline Time dummy (2006) & $0.07 * * *$ & 5.93 & $0.05^{* *}$ & 2.28 \\
\hline Time dummy (2007) & 0.03 & 0.88 & 0.02 & 0.05 \\
\hline Time dummy (2008) & -0.32 & -0.93 & -0.66 & -1.18 \\
\hline Time dummy (2009) & -0.19 & -0.25 & -0.48 & -0.66 \\
\hline Time dummy (2010) & 0.38 & 0.49 & 0.28 & 0.33 \\
\hline Time dummy (2011) & 1.73 & 0.81 & 0.99 & 0.26 \\
\hline Time dummy (2012) & 0.06 & 0.99 & 0.03 & 0.58 \\
\hline Time dummy (2013) & 0.93 & 0.82 & 0.06 & 0.32 \\
\hline Time dummy (2014) & 0.88 & 0.17 & 0.13 & 0.24 \\
\hline Time dummy (2015) & 2.17 & 0.91 & 1.93 & 0.35 \\
\hline Time dummy (2016) & 1.88 & 0.76 & 1.73 & 0.41 \\
\hline F test & \multicolumn{2}{|l|}{$716.87 * * *$} & \multicolumn{2}{|l|}{$826.72 * * *$} \\
\hline Sargan test $\mathrm{P}$ value & \multicolumn{2}{|l|}{0.589} & \multicolumn{2}{|l|}{0.253} \\
\hline $\operatorname{AR}(1)$ & -4.85 & 0.000 & -3.88 & 0.000 \\
\hline $\operatorname{AR}(2)$ & 1.06 & 0.247 & -1.41 & 0.158 \\
\hline No. of observations & \multicolumn{2}{|l|}{1200} & \multicolumn{2}{|l|}{1200} \\
\hline
\end{tabular}

$*, * *$ and $* * *$ denote significance at $10 \%, 5 \%$ and $1 \%$ levels, respectively. 
Table 6 Empirical results: The impacts of risk, efficiency and competition on bank profitability (Hirfindahl-Hirschman index as the competition indicator)

\begin{tabular}{|c|c|c|c|c|}
\hline & \multicolumn{2}{|l|}{ ROA } & \multicolumn{2}{|l|}{ NIM } \\
\hline & coefficient & t-statistic & Coefficient & t-statistic \\
\hline Lag of dependent variable & $0.27 * *$ & 2.15 & $0.58 * * *$ & 5.03 \\
\hline \multicolumn{5}{|l|}{ Bank characteristics } \\
\hline Credit risk & -0.0001 & -0.75 & 0.09 & 1.17 \\
\hline Liquidity risk & $-0.38 * *$ & -3.95 & -0.72 & -1.43 \\
\hline Capital risk & -0.00003 & -0.17 & $0.13 * *$ & 2.67 \\
\hline Insolvency risk & 0.02 & 1.18 & 0.02 & 0.03 \\
\hline Bank size & $-0.006^{*}$ & -1.59 & $-0.25 * * *$ & -3.93 \\
\hline Cost efficiency & $0.04 *$ & -1.72 & $3.98 * *$ & -5.07 \\
\hline Revenue efficiency & 0.001 & 0.09 & -0.43 & -0.59 \\
\hline Profit efficiency & $0.03 * *$ & 2.51 & $3.31 * *$ & 2.25 \\
\hline Bank diversification & 0.00003 & 0.90 & $-0.03 * * *$ & -7.73 \\
\hline \multicolumn{5}{|l|}{ Industry characteristics } \\
\hline $\begin{array}{l}\text { Hirfindahl-Hirschman index } \\
\text { (loan) }\end{array}$ & 2.14 & 0.48 & 5.93 & 1.26 \\
\hline $\begin{array}{l}\text { Hirfindahl-Hirschman index } \\
\text { (deposit) }\end{array}$ & -7.64 & -0.81 & -4.07 & -0.86 \\
\hline $\begin{array}{l}\text { Hirfindahl-Hirschman index } \\
\text { (non-interest income) }\end{array}$ & 1.94 & 0.80 & -111.16 & -0.72 \\
\hline Banking sector development & $0.009 * * *$ & 3.38 & 0.64 & 1.49 \\
\hline Stock market development & 0.00005 & 1.16 & 0.003 & 0.58 \\
\hline \multicolumn{5}{|l|}{ Macroeconomics } \\
\hline Inflation & $0.001 *$ & 1.78 & $0.11 * * *$ & 4.39 \\
\hline GDP growth rate & -0.0005 & 01.55 & 0.04 & 0.83 \\
\hline Time dummy (2003) & $0.28 * * *$ & 4.92 & $0.15 * * *$ & 4.48 \\
\hline Time dummy (2004) & $0.56 * * *$ & 4.77 & $0.11 * * *$ & 4.33 \\
\hline Time dummy (2005) & $0.34 * * *$ & 6.19 & $0.08 * * *$ & 5.13 \\
\hline Time dummy (2006) & $0.082 * * *$ & 5.93 & $0.05 * *$ & 2.28 \\
\hline Time dummy (2007) & 0.15 & 0.88 & 0.02 & 0.05 \\
\hline Time dummy (2008) & -0.23 & -0.93 & -0.66 & -1.18 \\
\hline Time dummy (2009) & -0.94 & -0.25 & -0.48 & -0.66 \\
\hline Time dummy (2010) & 0.47 & 0.49 & 0.28 & 0.33 \\
\hline Time dummy (2011) & 1.81 & 0.81 & 0.99 & 0.26 \\
\hline Time dummy (2012) & 0.05 & 0.99 & 0.03 & 0.58 \\
\hline Time dummy (2013) & $-0.09 * *$ & -2.88 & 0.15 & 0.52 \\
\hline Time dummy (2014) & 0.08 & 0.97 & 0.16 & 0.24 \\
\hline Time dummy (2015) & -1.27 & -0.82 & -0.87 & -0.53 \\
\hline Time dummy (2016) & 0.09 & 0.18 & 2.31 & 0.74 \\
\hline $\mathrm{F}$ test & \multicolumn{2}{|l|}{$76.90 * * *$} & \multicolumn{2}{|l|}{$826.72 * * *$} \\
\hline Sargan test $\mathrm{P}$ value & \multicolumn{2}{|l|}{0.598} & \multicolumn{2}{|l|}{0.255} \\
\hline $\mathrm{AR}(1)$ & -4.85 & 0.000 & -3.88 & 0.000 \\
\hline $\operatorname{AR}(2)$ & 1.06 & 0.247 & -1.41 & 0.158 \\
\hline No. of observations & \multicolumn{2}{|l|}{1200} & \multicolumn{2}{|l|}{1200} \\
\hline
\end{tabular}

$* * *$ and $* * *$ denote significance at $10 \%, 5 \%$ and $1 \%$ levels, respectively. 
Table 7 Empirical results: The impacts of risk, efficiency and competition on bank profitability (DEA)

\begin{tabular}{|c|c|c|c|c|}
\hline & \multicolumn{2}{|l|}{ ROA } & \multicolumn{2}{|l|}{ NIM } \\
\hline & coefficient & t-statistic & Coefficient & t-statistic \\
\hline Lag of dependent variable & $0.21 * *$ & 2.11 & $0.85 * * *$ & 5.87 \\
\hline \multicolumn{5}{|l|}{ Bank characteristics } \\
\hline Credit risk & -0.001 & -0.54 & 0.19 & 0.17 \\
\hline Liquidity risk & $-0.13 * *$ & -2.58 & -0.25 & -0.43 \\
\hline Capital risk & -0.0003 & -0.29 & $0.19 * *$ & 2.55 \\
\hline Insolvency risk & 0.04 & 1.11 & 0.08 & 0.04 \\
\hline Bank size & $-0.006^{*}$ & -1.89 & $-0.45 * * *$ & -3.38 \\
\hline Cost efficiency & $0.34 * * *$ & 3.88 & $0.57 * *$ & -2.57 \\
\hline Revenue efficiency & 0.01 & 0.19 & -0.34 & -0.19 \\
\hline Profit efficiency & $0.3 * *$ & 2.56 & $3.78 * *$ & 2.37 \\
\hline Bank diversification & 0.0003 & 0.29 & $-0.13 * * *$ & -7.37 \\
\hline \multicolumn{5}{|l|}{ Industry characteristics } \\
\hline Boone indicator (loan) & 2.14 & 0.84 & 5.93 & 0.26 \\
\hline Boone indicator (deposit) & -7.11 & -0.23 & -4.16 & -0.89 \\
\hline $\begin{array}{l}\text { Boone indicator (non- } \\
\text { interest income) }\end{array}$ & 1.94 & 0.66 & -111.16 & -0.27 \\
\hline Banking sector development & $0.09 * * *$ & 3.88 & 0.64 & 0.49 \\
\hline Stock market development & 0.0005 & 0.61 & 0.03 & 0.85 \\
\hline \multicolumn{5}{|l|}{ Macroeconomics } \\
\hline Inflation & $0.01 *$ & 1.69 & $0.11 * * *$ & 6.13 \\
\hline GDP growth rate & -0.005 & 0.77 & 0.04 & 0.39 \\
\hline Time dummy (2003) & $0.81 * * *$ & 5.51 & $0.51 * * *$ & 4.84 \\
\hline Time dummy (2004) & $0.15 * * *$ & 4.77 & $0.11 * * *$ & 4.33 \\
\hline Time dummy (2005) & $0.10^{* * *}$ & 6.92 & $0.08 * * *$ & 5.13 \\
\hline Time dummy (2006) & $0.07 * * *$ & 5.46 & $0.05 * *$ & 2.28 \\
\hline Time dummy (2007) & 0.03 & 0.93 & 0.02 & 0.05 \\
\hline Time dummy (2008) & -0.32 & -0.38 & -0.66 & -1.18 \\
\hline Time dummy (2009) & -0.19 & -0.52 & -0.48 & -0.66 \\
\hline Time dummy (2010) & 0.38 & 0.94 & 0.28 & 0.33 \\
\hline Time dummy (2011) & 1.73 & 0.18 & 0.99 & 0.26 \\
\hline Time dummy (2012) & 0.06 & 0.74 & 0.03 & 0.58 \\
\hline Time dummy (2013) & $2.28 * *$ & 2.79 & 0.75 & 0.47 \\
\hline Time dummy (2014) & 0.83 & 0.34 & $0.38 * *$ & 2.79 \\
\hline Time dummy (2015) & 1.15 & 0.99 & 0.09 & 0.08 \\
\hline Time dummy (2016) & -0.87 & -0.13 & 0.42 & 0.25 \\
\hline F test & \multicolumn{2}{|l|}{$112.35 * * *$} & \multicolumn{2}{|l|}{$862.18^{* * *}$} \\
\hline Sargan test $\mathrm{P}$ value & \multicolumn{2}{|l|}{0.439} & \multicolumn{2}{|l|}{0.737} \\
\hline $\mathrm{AR}(1)$ & -4.93 & 0.000 & -3.17 & 0.000 \\
\hline $\mathrm{AR}(2)$ & 1.28 & 0.333 & -1.17 & 0.512 \\
\hline No. of observations & \multicolumn{2}{|l|}{1200} & \multicolumn{2}{|l|}{1200} \\
\hline
\end{tabular}

$*, * *$ and $* * *$ denote significance at $10 \%, 5 \%$ and $1 \%$ levels, respectively. 
Table 8. Empirical results: The impacts of risk, efficiency and competition on bank profitability (alternative risk measurements)

\begin{tabular}{|c|c|c|c|c|}
\hline & \multicolumn{2}{|l|}{ ROA } & \multicolumn{2}{|l|}{ NIM } \\
\hline & coefficient & t-statistic & Coefficient & t-statistic \\
\hline Lag of dependent variable & $1.15 * *$ & 2.63 & $1.28 * * *$ & 6.94 \\
\hline \multicolumn{5}{|l|}{ Bank characteristics } \\
\hline Credit risk & -0.005 & -0.56 & 0.09 & 1.17 \\
\hline Liquidity risk & $-0.03 * *$ & -2.61 & -0.72 & -1.43 \\
\hline Capital risk & -0.0003 & -0.21 & $0.11 * *$ & 2.55 \\
\hline Insolvency risk & 0.03 & 1.08 & 0.02 & 0.03 \\
\hline Bank size & $-0.006^{*}$ & -1.38 & $-0.17 * * *$ & -3.23 \\
\hline Cost efficiency & $0.05^{*}$ & -1.88 & $3.93 * *$ & -2.18 \\
\hline Revenue efficiency & 0.005 & 0.29 & -0.31 & -0.38 \\
\hline Profit efficiency & $0.15 * *$ & 2.53 & $3.54 * *$ & 2.27 \\
\hline Bank diversification & 0.0003 & 0.88 & $-0.31 * * *$ & -6.38 \\
\hline \multicolumn{5}{|l|}{ Industry characteristics } \\
\hline Boone indicator (loan) & 2.38 & 0.85 & 5.33 & 0.26 \\
\hline Boone indicator (deposit) & -7.12 & -0.55 & -4.07 & -0.86 \\
\hline $\begin{array}{l}\text { Boone indicator (non- } \\
\text { interest income) }\end{array}$ & 1.49 & 0.73 & -110.16 & -0.27 \\
\hline Banking sector development & $0.09 * * *$ & 3.88 & 0.49 & 0.49 \\
\hline Stock market development & 0.0005 & 0.99 & 0.03 & 0.63 \\
\hline \multicolumn{5}{|l|}{ Macroeconomics } \\
\hline Inflation & $0.03 * *$ & 2.78 & 0.37 *** & 4.85 \\
\hline GDP growth rate & -0.005 & 0.59 & 0.04 & 0.37 \\
\hline Time dummy (2003) & $0.64 * * *$ & 5.83 & $0.29 * * *$ & 5.53 \\
\hline Time dummy (2004) & $0.57 * * *$ & 5.77 & $0.13 * * *$ & 6.83 \\
\hline Time dummy (2005) & $0.36 * * *$ & 8.38 & $0.12 * * *$ & 10.92 \\
\hline Time dummy (2006) & $0.18 * * *$ & 6.38 & $1.17 * *$ & 2.31 \\
\hline Time dummy (2007) & 0.13 & 0.74 & 0.02 & 0.37 \\
\hline Time dummy (2008) & -0.21 & -0.46 & -0.11 & -0.18 \\
\hline Time dummy (2009) & 1.13 & 0.11 & -0.87 & -0.14 \\
\hline Time dummy (2010) & 0.47 & 0.49 & 0.61 & 0.26 \\
\hline Time dummy (2011) & 2.58 & 0.16 & 0.18 & 0.69 \\
\hline Time dummy (2012) & 0.64 & 0.77 & 1.83 & 0.85 \\
\hline Time dummy (2013) & 2.85 & 0.93 & 0.95 & 0.59 \\
\hline Time dummy (2014) & -1.91 & -0.18 & -1.35 & -0.52 \\
\hline Time dummy (2015) & 0.83 & 0.34 & 0.34 & 0.22 \\
\hline Time dummy (2016) & 1.17 & 0.12 & $-2.52 * * *$ & -5.87 \\
\hline F test & \multicolumn{2}{|l|}{$76.90 * * *$} & \multicolumn{2}{|l|}{$826.72 * * *$} \\
\hline Sargan test $\mathrm{P}$ value & \multicolumn{2}{|l|}{0.633} & \multicolumn{2}{|l|}{0.189} \\
\hline $\mathrm{AR}(1)$ & -8.19 & 0.000 & -9.17 & 0.000 \\
\hline $\mathrm{AR}(2)$ & 1.06 & 0.317 & -1.41 & 0.536 \\
\hline No. of observations & \multicolumn{2}{|l|}{1200} & \multicolumn{2}{|l|}{1200} \\
\hline
\end{tabular}

$*, * *$ and $* * *$ denote significance at $10 \%, 5 \%$ and $1 \%$ levels, respectively. 
Table 9. Robustness check with Sub-periods 1

\begin{tabular}{|c|c|c|c|c|c|c|c|c|}
\hline & \multicolumn{4}{|l|}{ 2003-2009 } & \multicolumn{4}{|l|}{$2010-2017$} \\
\hline & \multicolumn{2}{|l|}{ ROA } & \multicolumn{2}{|l|}{ NIM } & \multicolumn{2}{|l|}{ ROA } & \multicolumn{2}{|l|}{ NIM } \\
\hline & coefficient & t-statistic & Coefficient & t-statistic & Coefficient & t-stat & Coefficient & t-stat \\
\hline Lag of dependent variable & $1.17 * *$ & 2.52 & $1.82 * * *$ & 5.88 & $1.93 * * *$ & 6.17 & $2.38 * * *$ & 5.98 \\
\hline \multicolumn{9}{|l|}{ Bank characteristics } \\
\hline Credit risk & $-0.05 * * *$ & -5.18 & $-0.09 * * *$ & -4.39 & $-0.03 * * *$ & -4.99 & $-0.06 * * *$ & -5.82 \\
\hline Liquidity risk & $-0.03 * *$ & -2.61 & -0.72 & -1.43 & $-0.02 * *$ & -2.88 & -1.83 & -0.37 \\
\hline Capital risk & $0.03 * * *$ & $9.15 * * *$ & $0.11 * *$ & 2.55 & $0.02 * *$ & 2.53 & $0.09 * *$ & 2.57 \\
\hline Insolvency risk & 0.03 & 1.08 & 0.02 & 0.03 & 0.08 & 0.98 & 0.17 & 0.73 \\
\hline Bank size & $-0.006^{*}$ & -1.63 & $-0.17 * * *$ & -3.23 & $-0.05 * * *$ & -3.95 & $-0.22 * *$ & -4.92 \\
\hline Cost efficiency & $0.03 *$ & 1.97 & $3.93^{*}$ & 1.89 & $0.01 * *$ & 2.62 & $2.77 *$ & 1.98 \\
\hline Revenue efficiency & 0.005 & 0.29 & -0.31 & -0.38 & 0.007 & 0.31 & -0.38 & -0.83 \\
\hline Profit efficiency & $0.11 *$ & 1.77 & $3.5 * *$ & 2.47 & $0.09 *$ & 1.88 & $2.7 * *$ & 2.65 \\
\hline Bank diversification & 0.003 & 0.73 & $-0.31 * * *$ & -6.38 & 0.035 & 0.37 & $-0.28 * * *$ & 4.91 \\
\hline \multicolumn{9}{|l|}{ Industry characteristics } \\
\hline Boone indicator (loan) & 2.19 & 0.55 & 5.19 & 0.63 & 1.87 & 0.19 & 4.88 & 0.85 \\
\hline Boone indicator (deposit) & -6.88 & -0.11 & -4.25 & -0.46 & -2.28 & -0.28 & -3.17 & -0.39 \\
\hline $\begin{array}{l}\text { Boone indicator (non- } \\
\text { interest income) }\end{array}$ & 0.67 & 0.22 & 0.12 & 0.23 & 0.71 & 0.34 & 0.29 & 0.38 \\
\hline Banking sector development & $0.09 * * *$ & 3.88 & $0.49 * *$ & 2.86 & $0.13 * * *$ & 4.11 & $0.58 * * *$ & 3.99 \\
\hline Stock market development & 0.0005 & 0.73 & 0.03 & 0.35 & 0.0008 & 0.66 & 0.17 & 0.58 \\
\hline \multicolumn{9}{|l|}{ Macroeconomics } \\
\hline Inflation & $0.03 * *$ & 2.95 & $0.61 * * *$ & 6.87 & $0.18 * * *$ & 3.39 & $0.91 * * *$ & 8.89 \\
\hline GDP growth rate & -0.05 & -0.21 & 0.24 & 0.75 & -0.87 & -0.28 & 0.42 & 0.66 \\
\hline Time dummy (2003) & $0.47 * * *$ & 6.38 & $0.29 * * *$ & 10.83 & & & & \\
\hline Time dummy (2004) & 0.57 & 0.79 & 0.13 & 0.83 & & & & \\
\hline Time dummy (2005) & 0.36 & 0.12 & 0.17 & 0.92 & & & & \\
\hline Time dummy (2006) & 0.18 & 0.62 & 1.28 & 0.31 & & & & \\
\hline Time dummy (2007) & $0.13 * * *$ & 7.41 & 0.02 & 0.37 & & & & \\
\hline Time dummy (2008) & -0.28 & -0.64 & -0.11 & -0.18 & & & & \\
\hline \multicolumn{9}{|l|}{ Time dummy (2009) } \\
\hline Time dummy (2010) & & & & & 0.57 & 0.11 & 0.44 & 0.31 \\
\hline
\end{tabular}




\begin{tabular}{|c|c|c|c|c|c|c|c|c|}
\hline Time dummy (2011) & & & & & 1.19 & 0.91 & 0.22 & 0.58 \\
\hline Time dummy (2012) & & & & & -0.18 & -0.02 & -1.87 & -0.99 \\
\hline Time dummy (2013) & & & & & 1.21 & 0.57 & 0.66 & 0.18 \\
\hline Time dummy (2014) & & & & & -0.83 & -0.47 & -1.18 & -0.99 \\
\hline Time dummy (2015) & & & & & 0.48 & 0.29 & 0.57 & 0.71 \\
\hline Time dummy (2016) & & & & & 1.13 & 0.33 & -2.28 & -0.81 \\
\hline F test & \multicolumn{2}{|c|}{$762.90 * * *$} & \multicolumn{2}{|c|}{$826.72 * * *$} & \multicolumn{2}{|c|}{$881.25 * * *$} & \multicolumn{2}{|c|}{$796.59 * * *$} \\
\hline Sargan test $\mathrm{P}$ value & \multicolumn{2}{|c|}{0.983} & \multicolumn{2}{|c|}{0.637} & \multicolumn{2}{|c|}{0.896} & \multicolumn{2}{|c|}{0.793} \\
\hline $\operatorname{AR}(1)$ & -8.83 & 0.000 & -6.42 & 0.000 & -9.83 & 0.000 & -8.61 & 0.000 \\
\hline $\mathrm{AR}(2)$ & 1.18 & 0.375 & -1.73 & 0.697 & 1.27 & 0.298 & -1.38 & 0.735 \\
\hline No. of observations & \multicolumn{2}{|l|}{548} & \multicolumn{2}{|l|}{548} & \multicolumn{2}{|l|}{652} & \multicolumn{2}{|l|}{652} \\
\hline
\end{tabular}

$*, * *$ and $* * *$ denote significance at $10 \%, 5 \%$ and $1 \%$ levels, respectively. 
Table 10. Robustness check with Sub-periods 2

\begin{tabular}{|c|c|c|c|c|c|c|c|c|}
\hline & \multicolumn{4}{|l|}{$2003-2006$} & \multicolumn{4}{|l|}{$2007-2017$} \\
\hline & \multicolumn{2}{|l|}{ ROA } & \multicolumn{2}{|l|}{ NIM } & \multicolumn{2}{|l|}{ ROA } & \multicolumn{2}{|l|}{ NIM } \\
\hline & coefficient & t-statistic & Coefficient & t-statistic & Coefficient & t-stat & Coefficient & t-stat \\
\hline Lag of dependent variable & $1.28 * * *$ & 3.63 & $1.35 * * *$ & 5.53 & $2.21 * * *$ & 4.47 & $2.25 * * *$ & 5.88 \\
\hline \multicolumn{9}{|l|}{ Bank characteristics } \\
\hline Credit risk & $-0.12 * * *$ & -5.56 & $-0.28 * * *$ & -4.48 & $-0.09 * * *$ & -4.98 & $-0.22 * * *$ & -4.34 \\
\hline Liquidity risk & $-0.05 * *$ & -2.81 & -0.68 & -1.39 & $-0.03 * *$ & -2.78 & -0.71 & -1.31 \\
\hline Capital risk & $0.07 * * *$ & 5.91 & $0.25 * *$ & 4.88 & $0.09 * * *$ & 6.28 & $0.28 * * *$ & 5.15 \\
\hline Insolvency risk & 0.02 & 0.98 & 0.05 & 0.13 & 0.03 & 0.85 & 0.12 & 0.17 \\
\hline Bank size & $-0.06 *$ & -1.66 & $-0.17 * * *$ & -3.23 & $-0.03 *$ & -1.76 & $-0.13 * * *$ & -4.11 \\
\hline Cost efficiency & $0.05 * * *$ & 3.88 & $3.95 * * *$ & 5.91 & $0.03 * * *$ & 3.91 & $2.88 * * *$ & 4.94 \\
\hline Revenue efficiency & 0.055 & 0.13 & -0.27 & -0.44 & 0.013 & 0.32 & -0.39 & -0.14 \\
\hline Profit efficiency & $0.15 * * *$ & 7.35 & $3.81 * * *$ & 10.91 & $0.18 * * *$ & 6.68 & $3.73 * * *$ & 9.91 \\
\hline Bank diversification & 0.003 & 0.71 & $-0.27 * * *$ & -5.83 & 0.008 & 0.18 & $-0.33 * * *$ & -4.48 \\
\hline \multicolumn{9}{|l|}{ Industry characteristics } \\
\hline Boone indicator (loan) & 2.38 & 0.56 & 5.28 & 0.29 & 2.25 & 0.61 & 4.49 & 0.31 \\
\hline Boone indicator (deposit) & -6.88 & -0.83 & $-3.99 * * *$ & -5.86 & -6.51 & -0.77 & $-4.11 * * *$ & -4.91 \\
\hline $\begin{array}{l}\text { Boone indicator (non-interest } \\
\text { income) }\end{array}$ & 1.55 & 0.89 & -108.62 & -0.33 & 1.47 & 0.95 & -101.17 & -0.28 \\
\hline Banking sector development & $0.07 * * *$ & 4.11 & 0.83 & 0.75 & $0.18 * * *$ & 5.53 & $0.23 * * *$ & 5.81 \\
\hline Stock market development & 0.005 & 0.11 & 0.05 & 0.34 & 0.007 & 0.17 & 0.06 & 0.41 \\
\hline \multicolumn{9}{|l|}{ Macroeconomics } \\
\hline Inflation & $0.13 * *$ & 3.87 & $0.73 * * *$ & 5.58 & $0.18 * * *$ & 4.12 & 0.86 *** & 5.57 \\
\hline GDP growth rate & -0.015 & -0.63 & 0.05 & 0.41 & -0.018 & -0.28 & 0.07 & 0.03 \\
\hline Time dummy (2003) & $0.44 * * *$ & 5.32 & $0.35 * * *$ & 5.85 & & & & \\
\hline Time dummy (2004) & $0.51 * * *$ & 5.81 & $0.32 * * *$ & 6.33 & & & & \\
\hline Time dummy (2005) & $0.38 * * *$ & 8.17 & $0.21 * * *$ & 11.18 & & & & \\
\hline \multicolumn{9}{|l|}{ Time dummy (2006) } \\
\hline Time dummy (2007) & & & & & 0.55 & 0.38 & 0.61 & 0.19 \\
\hline Time dummy (2008) & & & & & 0.61 & 0.46 & 0.58 & 0.22 \\
\hline Time dummy (2009) & & & & & 0.65 & 0.22 & 0.83 & 0.52 \\
\hline Time dummy (2010) & & & & & 0.81 & 0.23 & 0.73 & 0.19 \\
\hline Time dummy (2011) & & & & & 0.75 & 0.38 & 0.67 & 0.22 \\
\hline Time dummy (2012) & & & & & 0.68 & 0.41 & 0.59 & 0.26 \\
\hline Time dummy (2013) & & & & & 0.72 & 0.33 & 0.63 & 0.29 \\
\hline Time dummy (2014) & & & & & 0.65 & 0.25 & 0.61 & 0.21 \\
\hline Time dummy (2015) & & & & & 0.48 & 0.19 & 0.77 & 0.17 \\
\hline Time dummy (2016) & & & & & 0.59 & 0.88 & 0.52 & 0.23 \\
\hline
\end{tabular}




\begin{tabular}{|c|c|c|c|c|c|c|c|c|}
\hline F test & \multicolumn{2}{|c|}{$761.90 * * *$} & \multicolumn{2}{|c|}{$826.72 * * *$} & \multicolumn{2}{|c|}{$699.52 * * *$} & \multicolumn{2}{|c|}{$761.75 * * *$} \\
\hline Sargan test $\mathrm{P}$ value & \multicolumn{2}{|c|}{0.633} & \multicolumn{2}{|c|}{0.189} & \multicolumn{2}{|c|}{0.589} & \multicolumn{2}{|c|}{0.217} \\
\hline $\operatorname{AR}(1)$ & -8.19 & 0.000 & -9.17 & 0.000 & -8.28 & 0.000 & -8.09 & 0.000 \\
\hline $\mathrm{AR}(2)$ & 1.06 & 0.317 & -1.41 & 0.536 & 1.21 & 0.219 & -1.38 & 0.391 \\
\hline No. of observations & \multicolumn{2}{|l|}{412} & \multicolumn{2}{|l|}{412} & \multicolumn{2}{|l|}{788} & \multicolumn{2}{|l|}{788} \\
\hline
\end{tabular}

$*$,** and $* * *$ denote significance at $10 \%, 5 \%$ and $1 \%$ levels, respectively. 
Table 11. Empirical results: The impacts of risk, efficiency and competition on bank profitability (different ownership types)

\begin{tabular}{|c|c|c|c|c|c|c|c|c|c|c|c|c|}
\hline & \multicolumn{4}{|c|}{ State-owned commercial banks } & \multicolumn{4}{|c|}{ Joint-stock commercial banks } & \multicolumn{4}{|c|}{ City commercial banks } \\
\hline & \multicolumn{2}{|c|}{ ROA } & \multicolumn{2}{|l|}{ NIM } & \multicolumn{2}{|c|}{ ROA } & \multicolumn{2}{|l|}{ NIM } & \multicolumn{2}{|c|}{ ROA } & \multicolumn{2}{|l|}{ NIM } \\
\hline & coefficient & t-stat & coefficient & t-stat & Coefficient & t-stat & Coefficient & t-stat & $\begin{array}{l}\text { coeffic } \\
\text { ient }\end{array}$ & t-stat & $\begin{array}{l}\text { coeffic } \\
\text { ient }\end{array}$ & t-stat \\
\hline Lag of dependent variable & $0.49 * * *$ & 5.57 & $0.88 * *$ & 9.87 & $0.21 * *$ & 2.49 & $0.39 * *$ & 2.66 & $\begin{array}{l}0.18 * * \\
*\end{array}$ & 5.32 & $\begin{array}{l}0.11 * * \\
*\end{array}$ & 6.39 \\
\hline \multicolumn{13}{|l|}{ Bank characteristics } \\
\hline Credit risk & 0.05 & 0.25 & 0.03 & 0.28 & $-0.03 * * *$ & -3.87 & $-0.05 * * *$ & -4.12 & 0.03 & 0.09 & 0.05 & 0.07 \\
\hline Liquidity risk & 0.03 & 0.28 & 0.06 & 0.32 & 0.17 & 0.24 & 0.23 & 0.36 & 0.19 & 0.87 & 0.22 & 0.03 \\
\hline Capital risk & -0.01 & -0.03 & -0.01 & -0.05 & 1.15 & 0.98 & 1.23 & 0.86 & 1.19 & 0.19 & 2.28 & 0.62 \\
\hline Insolvency risk & 0.02 & 0.99 & 0.08 & 0.92 & 0.48 & 0.55 & 0.57 & 0.61 & 0.28 & 0.82 & 0.12 & 0.93 \\
\hline Bank size & $-0.07 * * *$ & -3.59 & $-0.08 * * *$ & -4.38 & $-0.12 * * *$ & -4.94 & $-0.28 * * *$ & -5.15 & $\begin{array}{l}- \\
0.18 * * \\
*\end{array}$ & -4.48 & $\begin{array}{l}- \\
0.22 * * \\
*\end{array}$ & -5.19 \\
\hline Cost efficiency & 0.06 & 0.16 & 0.03 & 0.29 & $0.08 * * *$ & 7.71 & $0.13 * * *$ & 9.55 & 0.16 & 0.62 & 0.18 & 0.29 \\
\hline Revenue efficiency & 0.09 & 0.53 & 0.02 & 0.35 & 1.21 & 0.03 & 1.33 & 0.05 & 0.19 & 0.03 & 0.003 & 0.28 \\
\hline Profit efficiency & 0.71 & 0.16 & 0.33 & 0.05 & 0.66 & 0.03 & 0.74 & 0.08 & $0.004 *$ & 1.61 & 0.0007 & 0.95 \\
\hline Bank diversification & $-0.08 * * *$ & -6.18 & $-0.05 * *$ & -5.15 & $-0.13 * * *$ & -6.25 & $-0.25 * * *$ & -7.17 & $-\overline{0.13 * *}$ & -2.58 & $-\overline{0.27 * *}$ & -2.73 \\
\hline \multicolumn{13}{|l|}{ Industry characteristics } \\
\hline Boone indicator (loan) & $0.01 * * *$ & 5.92 & $0.03 * * *$ & 6.38 & $0.08 * * *$ & 5.66 & $0.11 * * *$ & 7.99 & $\begin{array}{l}0.31 * * \\
*\end{array}$ & 6.17 & $0.48 * * *$ & 8.03 \\
\hline Boone indicator (deposit) & 0.23 & 0.35 & 0.17 & 0.51 & 1.21 & 0.05 & 1.38 & 0.23 & 0.07 & 0.28 & 0.11 & 0.33 \\
\hline $\begin{array}{l}\text { Boone indicator (non-interest } \\
\text { income) }\end{array}$ & 0.09 & 0.13 & 0.11 & 0.18 & $0.17 * * *$ & 4.41 & $0.19 * * *$ & 4.78 & 0.001 & 0.11 & 0.003 & 0.15 \\
\hline Banking sector development & $0.01 * * *$ & 6.19 & $0.04 * * *$ & 7.96 & $0.05 * * *$ & 6.28 & $0.09 * * *$ & 6.61 & $\begin{array}{l}0.03 * * \\
*\end{array}$ & 3.93 & $\begin{array}{l}0.03 * * \\
*\end{array}$ & 4.13 \\
\hline Stock market development & 0.003 & 0.88 & 0.005 & 0.88 & 0.02 & 0.73 & 0.01 & 0.58 & 0.0001 & 0.23 & 0.0005 & 0.12 \\
\hline \multicolumn{13}{|l|}{ Macroeconomics } \\
\hline Inflation & $0.03 * *$ & 2.88 & $0.28 * * *$ & 8.18 & $0.05^{* * *}$ & 3.34 & $0.31 * * *$ & 7.78 & $0.4 * * *$ & 4.17 & 0.42 & 3.99 \\
\hline GDP growth rate & 0.05 & 0.73 & 0.13 & 0.37 & 1.23 & 0.38 & 1.39 & 0.66 & 0.01 & 0.01 & 0.03 & 0.09 \\
\hline Constant & $2.38 * *$ & 11.29 & $2.12 * * *$ & 10.33 & $3.17 * * *$ & 15.19 & $3.31 * * *$ & 14.82 & $\begin{array}{l}2.21 * * \\
*\end{array}$ & 6.76 & $\begin{array}{l}2.28 * * \\
*\end{array}$ & 6.93 \\
\hline Time dummy (2003) & $0.18 * * *$ & 7.79 & $0.03 * * *$ & 6.82 & $0.22 * * *$ & 5.51 & $0.09 * * *$ & 6.65 & $\begin{array}{l}0.0003 \\
* * *\end{array}$ & 7.12 & $\begin{array}{l}0.0005 \\
* * *\end{array}$ & 7.96 \\
\hline Time dummy (2004) & $0.25 * * *$ & 6.81 & $0.79 * * *$ & 5.76 & $0.37 * * *$ & 4.15 & $0.82 * * *$ & 4.94 & $0.17 * *$ & 2.88 & $0.29 * *$ & 2.79 \\
\hline Time dummy (2005) & $0.11 * * *$ & 6.38 & $0.63 * * *$ & 5.95 & $0.31 * * *$ & 5.99 & $0.68 * * *$ & 6.13 & $\begin{array}{l}0.0002 \\
* * *\end{array}$ & 3.11 & $\begin{array}{l}0.0002 \\
* * *\end{array}$ & 3.55 \\
\hline Time dummy (2006) & 0.38 & 0.16 & 1.23 & 0.38 & 0.44 & 0.07 & 1.19 & 0.62 & 0.003 & 0.11 & 0.005 & 0.14 \\
\hline
\end{tabular}




\begin{tabular}{|c|c|c|c|c|c|c|c|c|c|c|c|c|}
\hline Time dummy (2007) & 0.67 & 0.19 & 1.42 & 0.41 & 0.76 & 0.11 & 1.48 & 0.29 & 0.015 & 0.011 & 0.023 & 0.032 \\
\hline Time dummy (2008) & 1.21 & 0.34 & 1.47 & 0.52 & 1.28 & 0.43 & 0.35 & 0.55 & 1.09 & 0.09 & 1.28 & 0.98 \\
\hline Time dummy (2009) & 1.37 & 0.48 & 1.13 & 0.55 & 0.98 & 0.69 & 0.99 & 0.95 & $0, .07$ & 0.84 & 0.56 & 0.006 \\
\hline Time dummy (2010) & 1.91 & 0.52 & 0.64 & 0.27 & 1.81 & 0.49 & 0.46 & 0.77 & 1.38 & 0.33 & 0.88 & 0.02 \\
\hline Time dummy (2011) & 1.35 & 0.41 & 0.63 & 0.99 & 1.33 & 0.47 & 0.36 & 0.92 & 0.05 & 0.51 & 0.07 & 0.17 \\
\hline Time dummy (2012) & 0.37 & 0.77 & 2.22 & 0.26 & 0.03 & 0.07 & 1.01 & 0.11 & 0.73 & 0.17 & 1.19 & 0.91 \\
\hline Time dummy (2013) & 0.56 & 0.49 & 1.17 & 0.16 & 0.78 & 0.04 & 1.44 & 0.63 & 0.91 & 0.09 & 0.03 & 0.31 \\
\hline Time dummy (2014) & 2.33 & 0.85 & 1.32 & 0.93 & 1.88 & 0.58 & 1.26 & 0.36 & 2.05 & 1.99 & 1.99 & 0.99 \\
\hline Time dummy (2015) & 1.91 & 0.44 & 0.97 & 0.68 & 1.17 & 0.64 & 0.81 & 0.28 & 1.01 & 0.97 & 0.98 & 0.86 \\
\hline Time dummy (2016) & 1.82 & 0.18 & 0.51 & 0.69 & 1.71 & 0.91 & 0.46 & 0.52 & 0.03 & 0.003 & 0.13 & 0.19 \\
\hline F test & \multicolumn{2}{|c|}{$78.85 * * *$} & \multicolumn{2}{|c|}{$79.96 * * *$} & \multicolumn{2}{|c|}{$88.85^{* * *}$} & \multicolumn{2}{|c|}{$91.17 * * *$} & \multicolumn{2}{|c|}{$95.59 * * *$} & \multicolumn{2}{|c|}{$91.68 * * *$} \\
\hline R square & \multicolumn{2}{|c|}{0.617} & \multirow{2}{*}{\multicolumn{2}{|c|}{0.782}} & 0.987 & & 0.843 & & 0.896 & & \multirow{2}{*}{\multicolumn{2}{|c|}{0.914}} \\
\hline No. of observations & 75 & & & & \multicolumn{2}{|c|}{180} & & & \multicolumn{2}{|l|}{945} & & \\
\hline
\end{tabular}

$* * *$ and $* * *$ denote significance at $10 \%, 5 \%$ and $1 \%$ levels, respectively.

Table 12. Empirical Results: The impacts of efficiency on bank profitability and how it changes with level of competition

\begin{tabular}{|c|c|c|c|c|c|c|c|c|c|c|c|c|}
\hline & \multicolumn{2}{|l|}{ ROA } & \multicolumn{2}{|l|}{ NIM } & \multicolumn{2}{|l|}{ ROA } & \multicolumn{2}{|l|}{ NIM } & \multicolumn{2}{|l|}{ ROA } & \multicolumn{2}{|l|}{ NIM } \\
\hline & coefficient & t-stat & coefficient & t-stat & Coefficient & t-stat & Coefficient & t-stat & $\begin{array}{l}\text { coeffic } \\
\text { ient }\end{array}$ & t-stat & $\begin{array}{l}\text { coeffic } \\
\text { ient }\end{array}$ & t-stat \\
\hline Lag of dependent variable & $0.22 * *$ & 2.28 & $0.63 * *$ & 8.78 & $0.28 * *$ & 2.55 & $0.39 * *$ & 2.87 & $\begin{array}{l}0.25 * * \\
*\end{array}$ & 3.35 & $\begin{array}{l}0.27 * * \\
*\end{array}$ & 3.64 \\
\hline \multicolumn{13}{|l|}{ Bank characteristics } \\
\hline Credit risk & 0.005 & 0.15 & 0.0018 & 0.22 & 0.007 & 0,21 & 0.003 & 0.21 & 0.006 & 0.16 & 0.007 & 0.11 \\
\hline Liquidity risk & $-0.02 * *$ & -2.88 & $-0.05 * *$ & -2.92 & $-0.02 * *$ & -2.89 & $-0.03 * *$ & -2.95 & $\begin{array}{l}- \\
0.03 * * \\
*\end{array}$ & -3.99 & $\begin{array}{l}- \\
0.05^{* *} \\
*\end{array}$ & -4.45 \\
\hline
\end{tabular}




\begin{tabular}{|c|c|c|c|c|c|c|c|c|c|c|c|c|}
\hline Capital risk & -0.0003 & -0.01 & -0.0001 & -0.03 & -0.0001 & -0.03 & -0.0002 & -0.07 & $\overline{-} .0003$ & -0.03 & $\overline{-} .0005$ & -0.01 \\
\hline Insolvency risk & 0.02 & 1.01 & 0.08 & 0.94 & 0.03 & 0.99 & 0.05 & 0.89 & 0.01 & 0.12 & 0.07 & 0.87 \\
\hline Bank size & $-0.007 * *$ & -2.35 & $-0.009 * *$ & -2.25 & $0.01 * * *$ & -3.11 & $-0.11 * * *$ & -3.23 & $-\overline{0.07 * *}$ & -2.68 & $-\overline{0}-01 * *$ & -2.59 \\
\hline Cost efficiency & $0.06^{* *}$ & 2.38 & $0.03 *$ & 1.79 & $0.08 * * *$ & 3.98 & $0.07 * * *$ & 3.17 & $0.12 * *$ & 2.52 & $0.09 * *$ & 2.68 \\
\hline Revenue efficiency & $0.09 * * *$ & 5.72 & $0.02 * *$ & 2.54 & 0.09 & 0.19 & 0.08 & 0.03 & 0.22 & 0.02 & 0.38 & 0.18 \\
\hline Profit efficiency & $0.71 * * *$ & 4.83 & $0.35^{* *}$ & 2.81 & 0.16 & 0.11 & 0.22 & 0.03 & 0.14 & 0.22 & 0.23 & 0.01 \\
\hline Bank diversification & $-0.08 * *$ & -2.57 & $-0.05 * *$ & -2.49 & $-0.11 * * *$ & -3.52 & $-0.07 * * *$ & -3.77 & 0.18 & 0.08 & 0.03 & 0.25 \\
\hline \multicolumn{13}{|l|}{ Industry characteristics } \\
\hline $\begin{array}{l}\text { Boone indicator (loan)-high } \\
\text { competition }\end{array}$ & 2.28 & 0.05 & & & & & & & & & & \\
\hline $\begin{array}{l}\text { Boone indicator (loan)-low } \\
\text { compeittion }\end{array}$ & & & 2.19 & 0.07 & & & & & & & & \\
\hline $\begin{array}{l}\text { Boone indicator (deposit)-high } \\
\text { competition }\end{array}$ & & & & & -6.65 & -0.98 & & & & & & \\
\hline $\begin{array}{l}\text { Boone indicator (deposit)-low } \\
\text { competition }\end{array}$ & & & & & & & -3.71 & -0.66 & & & & \\
\hline $\begin{array}{l}\text { Boone indicator (non-interest } \\
\text { income)-high competition }\end{array}$ & & & & & & & & & 0.09 & 0.87 & & \\
\hline $\begin{array}{l}\text { Boone indicator (non-interest } \\
\text { income)-low competition }\end{array}$ & & & & & & & & & & & 0.07 & 0.74 \\
\hline Banking sector development & $0.01 * * *$ & 6.19 & $0.03 * * *$ & 7.93 & $0.03 * * *$ & 5.57 & $0.09 * * *$ & 6.93 & $\begin{array}{l}0.05 * * \\
*\end{array}$ & 5.58 & $0.08 * * *$ & 7.97 \\
\hline Stock market development & 0.003 & 0.88 & $0.007 * *$ & 2.88 & 0.005 & 0.72 & 0.01 & 0.99 & 0.01 & 0.01 & 0.21 & 0.06 \\
\hline \multicolumn{13}{|l|}{ Macroeconomics } \\
\hline Inflation & $0.01 * *$ & 2.96 & $0.22 * * *$ & 7.93 & $0.08 * * *$ & 4.33 & $0.25 * * *$ & 5.19 & $\begin{array}{l}0.12 * * \\
*\end{array}$ & 3.93 & $\begin{array}{l}0.28 * * \\
*\end{array}$ & 4.12 \\
\hline GDP growth rate & 0.09 & 0.88 & $0.13 * * *$ & 7.87 & 0.08 & 0.18 & 0.15 & 0.55 & 0.12 & 0.03 & 0.09 & 0.81 \\
\hline F test & \multicolumn{2}{|l|}{$78.85 * * *$} & \multicolumn{2}{|l|}{$79.96 * * *$} & \multicolumn{2}{|l|}{$81.18 * * *$} & \multicolumn{2}{|l|}{$83.94 * * *$} & \multicolumn{2}{|c|}{$76.91 * * *$} & \multicolumn{2}{|c|}{$85.35 * * *$} \\
\hline Sargan test $P$ value & \multicolumn{2}{|l|}{0.617} & \multicolumn{2}{|l|}{0.392} & \multicolumn{2}{|l|}{0.468} & \multicolumn{2}{|l|}{0.573} & \multicolumn{2}{|c|}{0.626} & \multicolumn{2}{|l|}{0.598} \\
\hline $\operatorname{AR}(1)$ & -4.41 & 0.000 & -3.92 & 0.000 & -4.48 & 0.000 & -3.95 & 0.000 & -3.95 & 0.000 & -3.83 & 0.000 \\
\hline $\operatorname{AR}(2)$ & 1.17 & 0.317 & 1.19 & 0.176 & 1.05 & 0.254 & 1.31 & 0.457 & 1.43 & 0.293 & 1.66 & 0.341 \\
\hline No. of observations & \multicolumn{2}{|l|}{668} & \multicolumn{2}{|l|}{532} & \multicolumn{2}{|l|}{668} & \multicolumn{2}{|l|}{532} & \multicolumn{2}{|l|}{668} & \multicolumn{2}{|l|}{532} \\
\hline
\end{tabular}


Table 13. Empirical Results: The impacts of efficiency on bank profitability and how it changes with level of risk(credit risk and liquidity risk)

\begin{tabular}{|c|c|c|c|c|c|c|c|c|c|c|c|c|c|c|c|c|}
\hline & \multicolumn{2}{|l|}{ ROA } & \multicolumn{2}{|l|}{ ROA } & \multicolumn{2}{|l|}{ NIM } & \multicolumn{2}{|l|}{ NIM } & \multicolumn{2}{|l|}{ ROA } & \multicolumn{2}{|l|}{ ROA } & \multicolumn{2}{|l|}{ NIM } & \multicolumn{2}{|l|}{ NIM } \\
\hline & $\begin{array}{l}\text { coefficie } \\
\text { nt }\end{array}$ & t-stat & $\begin{array}{l}\text { Coeffi } \\
\text { cient }\end{array}$ & t-stat & $\begin{array}{l}\text { coefficie } \\
\text { nt }\end{array}$ & t-stat & $\begin{array}{l}\text { Coeffi } \\
\text { cient }\end{array}$ & t-stat & $\begin{array}{l}\text { Coeffi } \\
\text { cient }\end{array}$ & t-stat & $\begin{array}{l}\text { Coeffi } \\
\text { cient }\end{array}$ & t-stat & $\begin{array}{l}\text { Coeffici } \\
\text { ent }\end{array}$ & t-stat & $\begin{array}{l}\text { Coeffi } \\
\text { cient }\end{array}$ & t-stat \\
\hline $\begin{array}{l}\text { Lag of dependent } \\
\text { variable }\end{array}$ & $0.19 * * *$ & 3.38 & $\begin{array}{l}0.22 * \\
* *\end{array}$ & 3.73 & $0.17 * * *$ & 4.16 & $\begin{array}{l}0.19 * * \\
*\end{array}$ & 3.98 & $\begin{array}{l}0.22 * * \\
*\end{array}$ & 3.93 & $\begin{array}{l}0.25^{* *} \\
*\end{array}$ & 4.08 & $0.27 * * *$ & 4.15 & $\begin{array}{l}0.22 * * \\
*\end{array}$ & 4.23 \\
\hline \multicolumn{17}{|l|}{ Bank characteristics } \\
\hline Higher credit risk & -0.01 & -0.11 & & & 0.11 & 0.15 & & & & & & & & & & \\
\hline Low credit risk & & & -0.001 & -0.01 & & & 0.12 & 0.09 & & & & & & & & \\
\hline High liquidity risk & & & & & & & & & $-\overline{-} 21 * *$ & -2.67 & & & -0.33 & -0.11 & & \\
\hline Low liquidity risk & & & & & & & & & & & $\overline{-}-17 * *$ & -2.48 & & & -0.35 & -0.07 \\
\hline Bank size & $-0.09 * *$ & -2.57 & $\begin{array}{l}- \\
0.03 * \\
*\end{array}$ & -2.66 & $-0.11 * * *$ & -3.57 & $\begin{array}{l}- \\
0.13 * * \\
*\end{array}$ & -3.98 & $-\overline{0.13 * *}$ & -2.81 & $\begin{array}{l}- \\
0.33 * * \\
*\end{array}$ & -4.14 & $-0.26^{* *}$ & -2.61 & $\begin{array}{l}- \\
0.03 * * \\
*\end{array}$ & -3.88 \\
\hline Cost efficiency & $0.28 * * *$ & 4.36 & $\begin{array}{l}0.19 * \\
*\end{array}$ & 2.68 & $0.34 * * *$ & 4.67 & $\begin{array}{l}0.27 * * \\
*\end{array}$ & 5.72 & $\begin{array}{l}0.16^{* *} \\
*\end{array}$ & 3.38 & $\begin{array}{l}0.11 * * \\
*\end{array}$ & 3.72 & $0.25 * * *$ & 5.47 & $\begin{array}{l}0.09 * * \\
*\end{array}$ & 6.71 \\
\hline Revenue efficiency & 0.09 & 0.19 & 0.28 & 0.11 & 0.32 & 0.13 & 0.17 & 0.35 & 0.03 & 0.01 & 0.05 & 0.15 & 0.23 & 0.07 & 0.41 & 0.82 \\
\hline Profit efficiency & 0.11 & 0.03 & 0.71 & 0.02 & 0.47 & 0.68 & 0.19 & 0.06 & 0.03 & 0.01 & 0.07 & 0.04 & 0.001 & 0.11 & 0.21 & 0.04 \\
\hline Bank diversification & $-0.34 * *$ & -2.64 & $0.28 *$ & 1.82 & $0.03 * * *$ & 3.93 & $0.02 * *$ & 2.87 & $\begin{array}{l}0.21 * * \\
*\end{array}$ & 3.91 & $\begin{array}{l}0.27 * * \\
*\end{array}$ & 3.88 & $0.05 * *$ & 2.86 & $0.03 * *$ & 2.73 \\
\hline \multicolumn{17}{|l|}{$\begin{array}{l}\text { Industry } \\
\text { characteristics }\end{array}$} \\
\hline Boone indicator (loan) & $0.03 * *$ & 3.84 & $\begin{array}{l}0.04 * \\
* *\end{array}$ & 4.32 & $0.12 * * *$ & 5.27 & $\begin{array}{l}0.17 * * \\
*\end{array}$ & 4.94 & $\begin{array}{l}0.08 * * \\
*\end{array}$ & 7.68 & $0.1 * * *$ & 3.91 & $0.13 * * *$ & 3.44 & $0.2 * * *$ & 4.42 \\
\hline $\begin{array}{l}\text { Boone indicator } \\
\text { (deposit) }\end{array}$ & -6.68 & -0.96 & -5.32 & -0.87 & -5.78 & -0.77 & -6.12 & -0.79 & -6.63 & -0.73 & -5.98 & -0.69 & -6.08 & -0.82 & -5.99 & -0.89 \\
\hline $\begin{array}{l}\text { Boone indicator (non- } \\
\text { interest income) }\end{array}$ & 0.05 & 0.41 & 0.03 & 0.19 & 0.02 & 0.24 & 0.09 & 0.01 & 0.17 & 0.11 & 0.02 & 0.12 & 0.003 & 0.01 & 0.001 & 0.13 \\
\hline $\begin{array}{l}\text { Banking sector } \\
\text { development }\end{array}$ & $0.07 * * *$ & 3.87 & $\begin{array}{l}0.05 * \\
*\end{array}$ & 4.75 & 0.12 & 1.13 & 0.15 & 1.09 & $0.08 * *$ & 2.49 & $0.09 * *$ & 2.65 & 0.001 & 0.15 & 0.006 & 0.69 \\
\hline $\begin{array}{l}\text { Stock market } \\
\text { development }\end{array}$ & 0.003 & 0.13 & 0.001 & 0.18 & 0.005 & 0.21 & 0.003 & 0.09 & 0.007 & 0.19 & 0.006 & 0.2 & 0.004 & 0.06 & 0.005 & 0.07 \\
\hline \multicolumn{17}{|l|}{ Macroeconomics } \\
\hline Inflation & $0.03 * * *$ & 4.92 & $\begin{array}{l}0.02 * \\
*\end{array}$ & 2.78 & $0.013 * * *$ & 3.96 & $0.17 * *$ & 2.69 & $\begin{array}{l}0.021 * \\
* *\end{array}$ & 6.56 & $\begin{array}{l}0.018 * \\
*\end{array}$ & 2.86 & $\begin{array}{l}0.003 * * \\
*\end{array}$ & 3.94 & $\begin{array}{l}0.005^{*} \\
* *\end{array}$ & 5.95 \\
\hline GDP growth rate & 0.05 & 0.15 & 0.03 & 0.01 & 0.002 & 0.29 & 0.001 & 0.01 & 0.03 & 0.01 & 0.005 & 0.09 & 0.02 & 0.12 & 0.004 & 0.15 \\
\hline F test & \multicolumn{2}{|c|}{$101.19 * * *$} & \multicolumn{2}{|c|}{$99.83 * * *$} & \multicolumn{2}{|l|}{$97.17 * * *$} & \multicolumn{2}{|c|}{$121.96^{* * *}$} & \multicolumn{2}{|c|}{$138.76^{* * *}$} & \multicolumn{2}{|c|}{$100.98 * * *$} & \multicolumn{2}{|l|}{$97.64 * * *$} & \multicolumn{2}{|c|}{$121.21 * * *$} \\
\hline Sargan test $\mathrm{P}$ value & 0.892 & & 0.916 & & 0.878 & & 0.963 & & 0.989 & & 0.897 & & 0.883 & & 0.991 & \\
\hline
\end{tabular}




\begin{tabular}{|c|c|c|c|c|c|c|c|c|c|c|c|c|c|c|c|c|}
\hline $\mathrm{AR}(1)$ & -3.98 & 0.000 & -4.32 & 0.000 & -3.79 & 0.000 & -4.54 & 0.000 & -4.73 & 0.000 & -4.12 & 0.000 & -4.46 & 0.000 & -4.88 & 0.000 \\
\hline $\mathrm{AR}(2)$ & 1.18 & 0.198 & 1.27 & 0.253 & 1.43 & 0.382 & 1.39 & 0.412 & 1.41 & 0.436 & 1.37 & 0.431 & 1.64 & 0.444 & 1.97 & 0.749 \\
\hline No. of observations & 712 & & 488 & & 712 & & 488 & & 668 & & 532 & & 668 & & 532 & \\
\hline
\end{tabular}

$*, * *$ and $* * *$ denote significance at $10 \%, 5 \%$ and $1 \%$ levels, respectively.

Table 14. Empirical Results: The impacts of efficiency on bank profitability and how it changes with level of risk (capital risk and insolvency risk)

\begin{tabular}{|c|c|c|c|c|c|c|c|c|c|c|c|c|c|c|c|c|}
\hline & \multicolumn{2}{|l|}{ ROA } & \multicolumn{2}{|l|}{ ROA } & \multicolumn{2}{|l|}{ NIM } & \multicolumn{2}{|l|}{ NIM } & \multicolumn{2}{|l|}{ ROA } & \multicolumn{2}{|l|}{ ROA } & \multicolumn{2}{|l|}{ NIM } & \multicolumn{2}{|l|}{ NIM } \\
\hline & coefficient & t-stat & $\begin{array}{l}\text { coeffi } \\
\text { cient }\end{array}$ & t-stat & coefficient & t-stat & $\begin{array}{l}\text { coef } \\
\text { ficie } \\
\text { nt }\end{array}$ & t-stat & $\begin{array}{l}\text { coeffic } \\
\text { ient }\end{array}$ & t-stat & $\begin{array}{l}\text { coeffic } \\
\text { ient }\end{array}$ & t-stat & $\begin{array}{l}\text { coefficie } \\
\text { nt }\end{array}$ & t-stat & $\begin{array}{l}\text { coeffic } \\
\text { ient }\end{array}$ & t-stat \\
\hline $\begin{array}{l}\text { Lag of dependent } \\
\text { variable }\end{array}$ & $0.2 * * *$ & 3.19 & 0.21 & 3.27 & $0.21 * *$ & 2.88 & $\begin{array}{l}0.23 \\
* * *\end{array}$ & 3.53 & $0.31 * *$ & 2.59 & $0.29 * *$ & 2.68 & $0.28 * * *$ & 4.15 & $0.26 * *$ & 2.71 \\
\hline \multicolumn{17}{|l|}{ Bank characteristics } \\
\hline Higher capital risk & -0.01 & -0.13 & & & 0.13 & 0.05 & & & & & & & & & & \\
\hline Low capital risk & & & $\overline{-}-003$ & -0.05 & & & 0.18 & 0.12 & & & & & & & & \\
\hline High insolvency risk & & & & & & & & & 0.02 & 0.22 & & & -0.31 & -0.17 & & \\
\hline Low insolvency risk & & & & & & & & & & & 0.01 & 0.01 & & & -0.33 & -0.17 \\
\hline Bank size & $-0.07 * *$ & -2.49 & $\begin{array}{l}- \\
0.12 * \\
* *\end{array}$ & -3.66 & $-0.17 * * *$ & -4.15 & $\begin{array}{l}- \\
0.13 \\
* *\end{array}$ & -2.86 & $-\overline{0}-13^{* *}$ & -2.28 & $\begin{array}{l}- \\
0.33 * * \\
*\end{array}$ & -3.94 & $-0.28 * *$ & -2.65 & $\begin{array}{l}- \\
0.03 * * \\
*\end{array}$ & -3.79 \\
\hline Cost efficiency & $0.36 * * *$ & 4.38 & $\begin{array}{l}0.26^{*} \\
*\end{array}$ & 2.77 & $0.49 * * *$ & 4.43 & $\begin{array}{l}0.29 \\
* * *\end{array}$ & 4.48 & $0.16^{* *}$ & 2.76 & $0.11 * *$ & 2.71 & $0.25 * * *$ & 4.86 & $\begin{array}{l}0.09 * * \\
*\end{array}$ & 5.91 \\
\hline Revenue efficiency & 0.07 & 0.11 & 0.18 & 0.01 & 0.08 & 0.01 & 0.03 & 0.05 & 0.01 & 0.03 & 0.01 & 0.01 & 0.23 & 0.17 & 0.14 & 0.22 \\
\hline Profit efficiency & 0.09 & 0.05 & 0.68 & 0.13 & 0.42 & 0.86 & 0.09 & 0.15 & 0.05 & 0.11 & 0.07 & 0.43 & 0.001 & 0.12 & 0.01 & 0.04 \\
\hline Bank diversification & $0.38 * *$ & 2.68 & $0.14 *$ & 1.96 & $0.02 * * *$ & 3.92 & $\begin{array}{l}0.05 \\
* * *\end{array}$ & 4.57 & $0.31 * *$ & 2.66 & $0.35 * *$ & 3.19 & $0.33^{* * *}$ & 4.14 & $\begin{array}{l}0.34 * * \\
*\end{array}$ & 4.38 \\
\hline \multicolumn{17}{|l|}{$\begin{array}{l}\text { Industry } \\
\text { characteristics }\end{array}$} \\
\hline Boone indicator (loan) & $0.01 * *$ & 2.86 & $\begin{array}{l}0.09 * \\
*\end{array}$ & 2.78 & $0.19 * *$ & 2.69 & $\begin{array}{l}0.19 \\
* * *\end{array}$ & 3.86 & $\begin{array}{l}0.11 * * \\
*\end{array}$ & 5.11 & $0.1 * * *$ & 3.91 & $0.09 * * *$ & 3.49 & $\begin{array}{l}0.21 * * \\
*\end{array}$ & 4.38 \\
\hline $\begin{array}{l}\text { Boone indicator } \\
\text { (deposit) }\end{array}$ & -5.75 & -0.05 & -5.86 & -0.12 & -6.03 & -0.22 & $-\overline{5.95}$ & -0.55 & -5.13 & -0.48 & -5.56 & -0.03 & -5.18 & -0.28 & -5.49 & -0.19 \\
\hline
\end{tabular}




\begin{tabular}{|c|c|c|c|c|c|c|c|c|c|c|c|c|c|c|c|c|}
\hline $\begin{array}{l}\text { Boone indicator (non- } \\
\text { interest income) }\end{array}$ & 0.07 & 0.35 & 0.001 & 0.09 & 0.03 & 0.17 & 0.03 & 0.07 & 0.19 & 0.09 & 0.05 & 0.17 & 0.005 & 0.05 & 0.003 & 0.11 \\
\hline $\begin{array}{l}\text { Banking sector } \\
\text { development }\end{array}$ & $0.12 * * *$ & 3.99 & $0.11 *$ & 1.88 & 0.09 & 0.07 & 0.01 & 0.91 & $0.12 * *$ & 2.52 & $0.15^{* *}$ & 2.57 & 0.01 & 0.05 & 0.01 & 0.09 \\
\hline $\begin{array}{l}\text { Stock market } \\
\text { development }\end{array}$ & 0.006 & 0.03 & 0.001 & 0.22 & 0.005 & 0.02 & $\begin{array}{l}0.00 \\
3\end{array}$ & 0.12 & 0.007 & 0.12 & 0.006 & 0.02 & 0.04 & 0.12 & 0.05 & 0.17 \\
\hline \multicolumn{17}{|l|}{ Macroeconomics } \\
\hline Inflation & $0.09 * * *$ & 5.98 & $\begin{array}{l}0.02 * \\
* *\end{array}$ & 4.59 & $0.018 * * *$ & 4.94 & $\begin{array}{l}0.17 \\
* * *\end{array}$ & 4.47 & $\begin{array}{l}0.02 * * \\
*\end{array}$ & 4.92 & $\begin{array}{l}0.018^{*} \\
* *\end{array}$ & 3.83 & $0.03 * * *$ & 4.18 & $\begin{array}{l}0.05^{* *} \\
*\end{array}$ & 4.33 \\
\hline GDP growth rate & 0.01 & 0.05 & 0.03 & 0.03 & 0.003 & 0.16 & $\begin{array}{l}0.00 \\
1\end{array}$ & 0.03 & 0.01 & 0.03 & 0.005 & 0.19 & 0.02 & 0.11 & 0.04 & 0.29 \\
\hline F test & \multicolumn{2}{|c|}{$109.26 * * *$} & \multicolumn{2}{|c|}{$100.11 * * *$} & \multicolumn{2}{|l|}{$98.89 * * *$} & \multicolumn{2}{|c|}{$99.19 * * *$} & \multicolumn{2}{|c|}{$121.76^{* * *}$} & \multicolumn{2}{|c|}{$119.98 * * *$} & \multicolumn{2}{|c|}{$121.64 * * *$} & \multicolumn{2}{|c|}{$121.92 * * *$} \\
\hline Sargan test $\mathrm{P}$ value & \multicolumn{2}{|l|}{0.781} & \multicolumn{2}{|c|}{0.793} & \multicolumn{2}{|l|}{0.877} & \multicolumn{2}{|c|}{0.912} & \multicolumn{2}{|c|}{0.927} & \multicolumn{2}{|l|}{0.934} & \multicolumn{2}{|l|}{0.973} & \multicolumn{2}{|l|}{0.995} \\
\hline $\mathrm{AR}(1)$ & -4.14 & 0.000 & -4.29 & 0.000 & -3.7969 & 0.000 & - & 0.000 & -4.33 & 0.000 & -4.26 & 0.000 & -4.64 & 0.000 & -4.49 & 0.000 \\
\hline $\mathrm{AR}(2)$ & 1.41 & 0.198 & 1.63 & 0.253 & 1.55 & 0.382 & 1.38 & 0.443 & 1.47 & 0.445 & 1.42 & 0.418 & 1.46 & 0.437 & 1.79 & 0.751 \\
\hline No. of observations & \multicolumn{2}{|l|}{598} & \multicolumn{2}{|l|}{602} & \multicolumn{2}{|l|}{598} & \multicolumn{2}{|l|}{602} & \multicolumn{2}{|l|}{418} & \multicolumn{2}{|l|}{782} & \multicolumn{2}{|l|}{418} & \multicolumn{2}{|l|}{782} \\
\hline
\end{tabular}

$*, * *$ and $* * *$ denote significance at $10 \%, 5 \%$ and $1 \%$ levels, respectively. 